\title{
Genes involved in human premature ovarian failure
}

\author{
Luca Persani ${ }^{1,2}$, Raffaella Rossetti ${ }^{1}$ and Chiara Cacciatore ${ }^{2,3}$ \\ ${ }^{1}$ Dipartimento di Scienze Mediche, Università degli Studi di Milano, Milan I-20100, Italy \\ ${ }^{2}$ Laboratorio di Ricerche Endocrinologiche, IRCCS Istituto Auxologico Italiano, Milan I-20100, Italy \\ ${ }^{3}$ Unità di Endocrinologia, Fondazione IRCCS Ca' Granda Policlinico, Milan I-20100, Italy \\ (Correspondence should be addressed to L Persani who is now at Laboratorio di Ricerche Endocrinologiche, Dipartimento di Scienze Mediche, \\ IRCCS Istituto Auxologico Italiano, Università di Milano, Via Zucchi 18, 20095 Cusano, Milan, Italy; Email: Iuca.persani@unimi.it)
}

\begin{abstract}
Premature ovarian failure (POF) is an ovarian defect characterized by the premature depletion of ovarian follicles before the age of 40 years, representing one major cause of female infertility. POF relevance is continuously growing because women tend to conceive ever more frequently in their thirties and forties. POF can present very early with a pubertal defect. More frequently, it is the end stage of an occult process (primary ovarian insufficiency, POI) affecting $\sim 1-2 \%$ of under- 40 women. $\mathrm{POI}$ is a heterogeneous disease caused by a variety of mechanisms. Though the underlying cause remains unexplained in the majority of cases, various data indicate that POI has a strong genetic component. These data include the existence of several causal genetic defects in humans, experimental and natural models, as well as the frequent familiarity. The variable expressivity of $\mathrm{POI}$ defect in women of the same family may indicate that, in addition to some monogenic forms, POI may frequently be considered as a multifactorial defect resulting from the contribution of several predisposing alleles. The $\mathrm{X}$ chromosome-linked defects play a major role among the presently known causal defects. Here, we review the principal X-linked and autosomal genes involved in syndromic and nonsyndromic forms of $\mathrm{POI}$ with the wish that this list will soon become upgraded because of the discovery of novel contributing mechanisms. A better understanding of POI pathogenesis will indeed allow the construction of tests able to predict the age of menopause in women at higher risk of POI.
\end{abstract}

Journal of Molecular Endocrinology (2010) 45, 257-279

\section{Introduction}

The median age of natural menopause in Caucasian women is $50 \pm 1$ years (Morabia \& Costanza 1998); however, $\sim 1 \%$ of women under the age of 40 years and $0.1 \%$ under the age of 30 years experience premature menopause (Coulam et al. 1986). Premature ovarian failure (POF) is classically defined as $4-6$ months of amenorrhea in women under the age of 40 years associated with menopausal level of serum gonadotropins (FSH > $30 \mathrm{U} / \mathrm{l}$ ) and hypoestrogenism and is also referred as hypergonadotropic hypogonadism. Depending on the age of onset, the disorder can manifest as primary amenorrhea (PA), without menarche, or secondary amenorrhea (SA) after the pubertal development (Timmreck \& Reindollar 2003). Based on evidence that POF has a long and variable clinical course, it has been recently proposed the term of primary ovarian insufficiency (POI), as a more scientifically accurate definition, to better describe the progression toward the cessation of ovarian function (Welt 2008, Nelson 2009). POI generates two types of consequence. One is premature hypoestrogenism, which in turn causes the premature aging of several tissues, targets of estrogen action, and thus increasing the risk of osteoporosis, cardiovascular diseases, or neurodegenerative diseases. The second consequence is infertility. Hypoestrogenism can nowadays be satisfactorily treated by hormone replacement therapy to be generally given until the age of physiological menopause. In contrast, fertility cannot be recovered when the diagnosis of POF (or end-stage POI) is generally reached, and is often compromised in the early phases of the disease when the clinical manifestations are absent. For this reason, research in this field aims at the identification of markers able to predict the premature cessation of menses, thus allowing women at risk of POF to plan an early conception. Biochemical markers (FSH, estradiol $\left(\mathrm{E}_{2}\right)$, inhibin $\mathrm{B}$, or anti-Mullerian hormone $(\mathrm{AMH})$ ) 
are nowadays mainly useful to confirm a diagnosis indicated by menstrual irregularity. Prediction of POI therefore relies on a better understanding of its pathogenesis.

\section{Mechanisms leading to a premature impairment of the ovarian reserve}

Around 7 million primordial follicles are present in the developing ovary during embryogenesis (Fig. 1A). The large majority of these follicles are lost during fetal and postnatal life by atresia, and only 400-500 of them are generally ovulated before physiological menopause. Instead, as shown in Fig. 1B, the possible mechanisms at the origin of POI can be a) an initial decrease in the primordial follicle pool; b) an accelerated follicular atresia; or c) an altered maturation/recruitment of primordial follicles. However, in most of the cases, including a subset associated with PA and gonadal dysgenesis (Reynaud et al. 2004, Fechner et al. 2006), ovarian insufficiency occurs because of an anticipated depletion of the primordial follicular pool. The etiological causes that may activate such mechanisms are highly heterogeneous and include chromosomal, genetic, autoimmune, metabolic, infectious, and iatrogenic factors (Goswami \& Conway 2005). At present, about $25 \%$ of all forms of POF can be classified as iatrogenic and are related to cancer treatment, but more than $50 \%$ of the cases remain idiopathic, so that the origin of POI is still largely unknown.

\section{Is genetic origin prevalent in POI?}

Several observations support a prevalent role of genetic mechanisms in the pathogenesis of idiopathic POI.

First, the ovarian defect of patients with Turner's syndrome (TS) or related X chromosome abnormalities indicates the essential role played by X-linked genes in ovarian function. Furthermore, the genetic origin of POI is supported by the existence of monogenic forms in humans and animal models indicating also the relevance of non-X genetic loci for POI pathogenesis. Another clue is the important role of familiarity in the determination of menopausal age. Epidemiological evidences support the heritability of menopausal age between mothers and daughters (Cramer et al. 1995, Torgerson et al. 1997, Murabito et al. 2005), and recent genome-wide studies found loci on chromosomes 5, 6, 13, 19, and 20, which were significantly associated with age at natural menopause (He et al. 2009, Perry et al. 2009). Interestingly, POI has also a frequent familial incidence. In large series of POF women, the incidence of familial forms ranges from 4 to $31 \%$, depending on the population

A

\begin{tabular}{lc|}
\cline { 2 - 2 } & \multicolumn{2}{c|}{ Follicular dynamics in physiology } \\
\hline \multicolumn{3}{c}{$\begin{array}{c}\text { Number of total follicles } \\
\text { (primordial/primary) }\end{array}$} \\
Life stages & $7 \times 10^{6}$ \\
Gestation (20th week) & $1 \times 10^{6}$ \\
Birth & 300000 \\
Puberty & $<1000$ \\
Pre-menopause & 0
\end{tabular}

B

Stages of the folliculogenesis

Gonadotrophin independent

Gonadotrophin independent

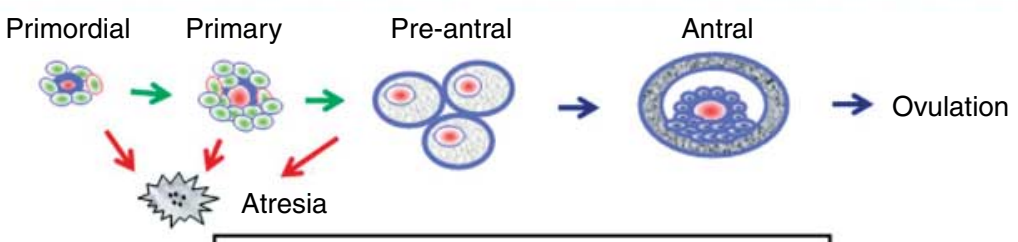

Possible mechanism at the origin of POI

$\downarrow$ Number of primordial follicles

$\uparrow$ Atresia

Altered follicular maturation

Figure 1 (A) Follicular dynamics and illustration of the folliculogenesis process in physiology. (B) The possible mechanisms generating POI may affect different stages of folliculogenesis. 
Table 1 List of genetic defects associated with primary ovarian insufficiency (POI)

Frequency in POI

$X$ chromosome defects

Turner's syndrome and related defects

Fragile $\mathrm{X}$ syndrome (FMR1 premutation)

DIAPH2 disruption (translocation)

$B M P 15$ variants

PGRMC1 variants

Autosomal defects

Complex diseases

Galactosemia (GALT), BPES (FOXL2), APECED

(AIRE), mitochondrial (POLG), Demirhan syndrome

(BMPR1B), PHP1a (GNAS), ovarian leukodystrophy

(EIF2B), ataxia telangiectasia (ATM)

Isolated diseases

$\mathrm{FSH} / \mathrm{LH}$ resistance ( $F S H R$ and $L H R)$

INHA variants

GDF9 variants

NOBOX variants

NR5A1 variants

Meiotic gene variants

FIGLA mutations

\section{Frequency in POI}

Principal references

\begin{tabular}{|c|c|}
\hline $4-5 \%$ & Zinn \& Ross (1998) \\
\hline $3-15 \%$ & Marozzi et al. (2000) and Wittenberger et al. (2007) \\
\hline Unknown & Bione et al. (1998) \\
\hline $1 \cdot 5-12 \%$ & $\begin{array}{l}\text { Di Pasquale et al. (2004), Dixit et al. (2006a), } \\
\text { Laissue et al. (2006), Rossetti et al. (2009), } \\
\text { Wang et al. (2010) and Tiotiu et al. (2010) }\end{array}$ \\
\hline $1 \cdot 5 \%$ & Mansouri et al. (2008) \\
\hline Rare & $\begin{array}{l}\text { Sedgwick \& Boder (1991), Perheentupa (1996), } \\
\text { Weinstein et al. (2004), Fogli et al. (2003, 2004), } \\
\text { Beysen et al. (2009), Luoma et al. (2004), } \\
\text { Demirhan et al. (2005), Pagnamenta et al. (2006) } \\
\text { and Calderon et al. (2007) }\end{array}$ \\
\hline$<1 \%$ & $\begin{array}{l}\text { Aittomaki et al. (1995), Latronico et al. (1996), } \\
\text { Beau et al. (1998) and Touraine et al. (1999) }\end{array}$ \\
\hline Unknown & $\begin{array}{l}\text { Shelling et al. (2000), Marozzi et al. (2002), } \\
\quad \text { Dixit et al. }(2004,2006 \text { b) and Corre et al. (2009) }\end{array}$ \\
\hline $1 \cdot 4 \%$ & $\begin{array}{l}\text { Dixit et al. (2005), Laissue et al. (2006), } \\
\quad \text { Kovanci et al. (2007) and Zhao et al. (2007) }\end{array}$ \\
\hline $\begin{array}{l}0 \% \text { in Asiatics; } 1 \% \\
\text { in North Americans }\end{array}$ & Zhao et al. (2005) and Qin et al. (2007, 2009) \\
\hline $8 \%$ in 25 Europeans & Lourenço et al. (2009) \\
\hline Rare & Mandon-Pépin et al. (2008) \\
\hline $2 \%$ (in 100 Chinese) & $(2008 a, b)$ \\
\hline
\end{tabular}

studied, but this percentage can increase further if a familial history of early menopause (EM) between 40 and 45 years of age is considered (Conway et al. 1996, Vegetti et al. 1998). Pedigree analysis demonstrates different modes of inheritance, including dominant or recessive forms either through maternal or paternal transmission (Vegetti et al. 1998). The more frequent maternal transmission would be consistent with an X-linked inheritance with incomplete penetrance (Davis et al. 2000, Toniolo 2006, Persani et al. 2009). However, the presence in the same pedigree of women with PA, POF, or EM indicates that POI may be a genetic disease with a highly variable expressivity (Tibiletti et al. 1999), thus supporting the view of POI as a complex multifactorial disease probably involving the contribution of several alleles (Toniolo 2006). The purpose of this review is to illustrate the principal genes involved in the pathogenesis of POI (Table 1 and Fig. 2), either when ovarian failure arises apparently isolated in a woman before 40 years of age (nonsyndromic forms) or when this defect is part of a complex phenotype involving other organs and tissues (syndromic forms). Researches are focused in the past years on the candidate gene approach, mostly based on animal models of the pathology, which permitted to identify several genetic variations associated with POI. Very recently, genome-wide studies are beginning to emerge as a novel and alternative approach for finding novel candidate genes and chromosomal loci.

\section{Syndromic POI}

\section{Turner's syndrome}

Many forms of familial as well as sporadic POI implicate $\mathrm{X}$ chromosome aberrations that range from numerical defects, such as the $\mathrm{X}$ monosomy (TS) and trisomy $\mathrm{X}$, to structural defects, such as deletions, isochromosomes, and balanced X-autosomal translocations (Zinn 2001). TS is the consequence of complete or partial absence of one $\mathrm{X}$ chromosome in a phenotypic female usually associated with short stature and infertility (Sybert \& McCauley 2004). In about $50 \%$ of the cases, there is complete loss of one $\mathrm{X}$ chromosome, whereas the remaining TS patients harbor mosaicism or structural abnormalities of the $\mathrm{X}$ chromosome resulting in a milder phenotype (Bharath et al. 2010). The prevalence of the disorder is about 1:2500 live female births (Sybert \& McCauley 2004). In women with 45,X karyotype, oocyte loss occurs in the early stages of meiotic prophase, resulting in gonadal dysgenesis and PA with 


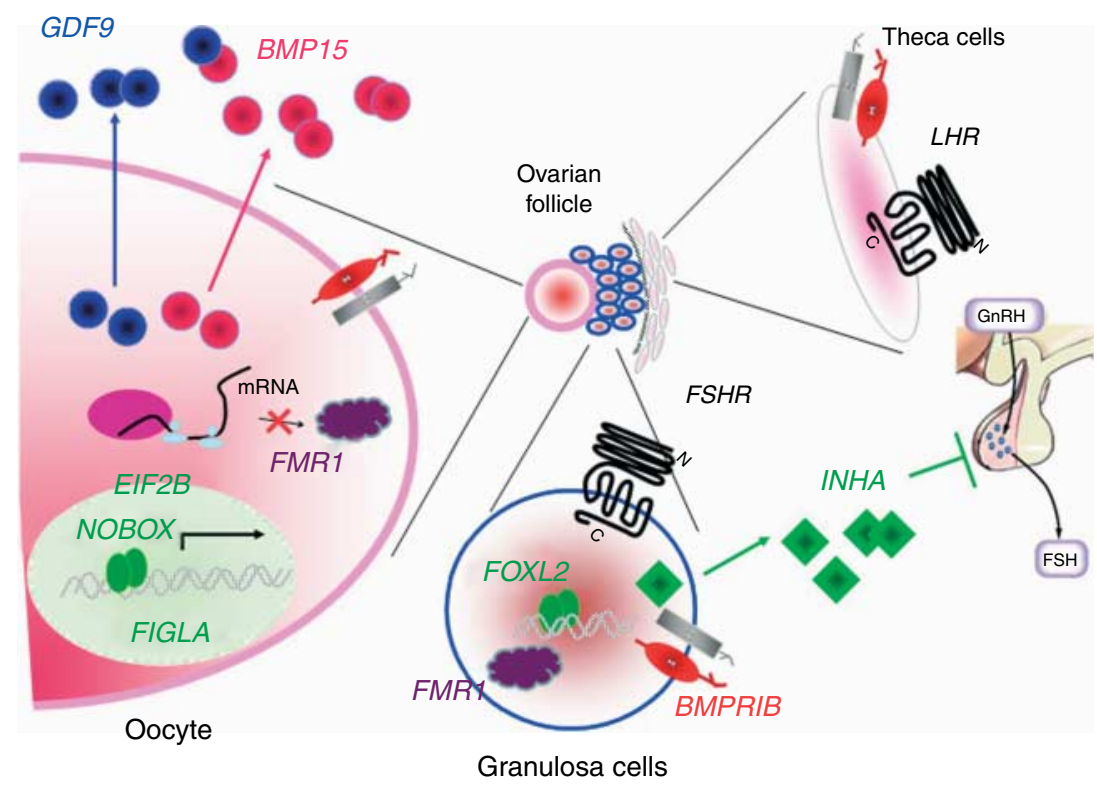

Figure 2 Schematic illustration of the principal genes known to be involved in POI pathogenesis and their site of expression in the ovary.

elevated FSH levels since early childhood (Reynaud et al. 2004, Fechner et al. 2006). However, spontaneous menarche and pregnancy have been reported not only in patients with mosaic karyotype, but also in few nonmosaic 45,X women (Pasquino et al. 1997, Cools et al. 2004, Livadas et al. 2005). The TS phenotype may be explained by several mechanisms, including the defective pairing of $\mathrm{X}$ chromosomes at meiosis (Ogata \& Matsuo 1995), but the most substantiated one is the haploinsufficiency of X-linked genes (such as SHOX) that physiologically escape $\mathrm{X}$ chromosome inactivation and are needed in two copies for ovarian function (Zinn \& Ross 1998). The requirement for a double dosage of certain X-linked genes is supported by the observation that complete spontaneous puberty can be reached in 30-40\% of mosaic Turner patients (Pasquino et al. 1997). Consistently, 45,X subjects have FSH levels already in the postmenopausal range during infancy, whereas FSH levels are frequently low in mosaic Turner patients of the same age (Fechner et al. 2006). The mechanism supporting pubertal development in a small subset of $45, \mathrm{X}$ Turner patients is presently unexplained, but low mosaic percentages undetected at standard karyotyping might be a possible explanation.

Cytogenetic and molecular analyses of POI women carrying a balanced $\mathrm{X}$-autosome translocation allowed the identification of a 'critical region' for ovarian development and function on the long arm of the X chromosome from Xq13.3 to q27. This region could be split into two functionally different portions: Xq13-21 and Xq23-27 (Therman et al. 1990, Rizzolio et al. 2006). In balanced translocations, most breakpoints involve the region Xq13-q21, while only interstitial deletions in Xq23-q27 were found associated with POI. Alternative mechanisms proposed for the explanation of the ovarian defect account for the size of the critical Xq region (Toniolo 2006). They include the direct disruption of relevant loci or a 'position effect' caused by the rearrangements on contiguous genes. The 'position effect' is a mechanism involving the deletion or translocation of regulatory domains to different position on the genome that might cause changes in gene transcription. Transcriptional characterization of breakpoint regions in $>40$ balanced translocations led to the identification of five genes interrupted by translocations: the XPNPEP2 (MIM *300145) gene in Xq25 (Prueitt et al. 2000), the POF1B (MIM *300603) gene in $\mathrm{Xq} 21.2$, the $\mathrm{DACH} 2$ (MIM *300608) gene in Xq21.3 (Bione et al. 2004), the CHM (MIM *300390) gene in Xq21.2 (van Bokhoven et al. 1994), and the DIAPH2 (MIM *300108) gene in Xq22 (Bione et al. 1998). Only the DIAPH2 gene, a human homolog of the Drosophila melanogaster diaphanous gene affecting spermatogenesis and oogenesis, was found disrupted by a breakpoint in a family with POI, but no mutation demonstrated its role in ovarian function nor that of the others candidates. However, most breakpoints described in POI patients were frequently mapped in Xq21, outside of genic regions, consistent with models for POI associated with $\mathrm{X}$ to autosome translocations that involve extra X chromosome effects (Mumm et al. 2001, Prueitt et al. 2002). These observations suggest the hypothesis that chromosomal rearrangements due to an epigenetic effect of the active $\mathrm{X}$ chromosome may 
account for a position effect on promoters of autosomal genes when involved in balanced translocations (Rizzolio et al. 2007). Recently, heterochromatin rearrangements of the Xq13-q21 region were reported to downregulate oocyte-expressed genes during oocyte and follicle maturation indicating that X-linked POI may be an epigenetic disorder (Rizzolio et al. 2009). Another model suggests that some translocations adversely affect $\mathrm{X}$ chromosome structure leading to defective meiotic pairing that might increase apoptosis of germ cells at meiotic checkpoints (Schlessinger et al. 2002), thereby leading to POI.

\section{Carbohydrate-deficient glycoprotein syndromes and galactosemia}

Genetic defects of enzymes providing glycosylation of proteins (carbohydrate-deficient glycoprotein syndromes) are rare and complex diseases are generally characterized by severe systemic disorders. The clinical presentation and course are highly variable, ranging from death in infancy to mildly involved adults (Sparks $\&$ Krasnewich 2009). In these cases, ovarian defects may be seen indicating that a defective glycosylation of ovarian glycoproteins is critical for ovarian function.

Galactosemia (MIM \#230400) is a hereditary disorder of galactose metabolism caused by the deficiency of GALT (MIM *606999) enzyme (galactose-1-phosphatase uridyltransferase). The incidence of this disease in Europe and North America is about 1:30 000-1:50 000 (Rubio-Gozalbo et al. 2010). Galactosemia presents with the worst complications in organs with high GALT expression, such as liver, kidney, ovary, and heart. More than 220 mutations have been described in GALT gene (Calderon et al. 2007); however, two common mutations (Q188R and K285N) account for more than $70 \%$ of cases associated with impaired GALT function (Tyfield et al. 1999). POI occurs in almost all women homozygous for mutations in the GALT gene that partially or completely abolishes GALT activity and is associated with a severe phenotype (Waggoner et al. 1990). FSH levels can be increased from birth to puberty (Steinmann et al. 1981, Schwarz et al. 1984, Rubio-Gozalbo et al. 2006), and the timing of the damage to the ovary is quite different. More frequently, streak ovaries or few primordial follicles failing to mature have been reported (Robinson et al. 1984, Fraser et al. 1986, Sauer et al. 1991). Pathogenetic mechanisms at the origin of galactosemia are not well understood, but several hypotheses have been proposed. Ovarian damage can be induced by toxic accumulation of galactose metabolites that cause oocyte apoptosis (Liu et al. 2000) or by deficiency of galactose-containing glycoproteins and/or glycolipids involving FSH and its receptor, causing in turn a decreased ovarian stimulation and an increased follicle atresia (Tedesco \& Miller 1979, Jaeken et al. 1992, Ornstein et al. 1992). As a word of caution, it should be kept in mind that spontaneous pregnancies have been reported in a few women with galactosemia, even when biochemical markers (undetectable AMH, $\mathrm{E}_{2}$, and high gonadotropins) were indicative of ovarian failure (Gubbels et al. 2008).

\section{Pseudohypoparathyroidism type 1a}

The first intracellular element downstream gonadotropin receptors is Gs $\alpha$, the $\mathrm{G}$ protein whose activation couples the stimulation of FSH and LH receptors (FSHR and LHR) to their enzymatic effector, adenylyl cyclase. This protein is encoded by a gene locus (GNAS1; MIM + 139320) on chromosome 20q13 that is subject to parental imprinting (Weinstein et al. 2004, Mantovani \& Spada 2006). GNAS1 loss-of-function variants inherited from the mother are known to cause a generalized form of hormone resistance named pseudohypoparathyroidism type 1a (Patten \& Levine 1990), which is the first syndrome of hormone resistance, which was described by Albright et al. (1942) and also named as Albright's hereditary osteodystrophy. The presence of gonadotropin resistance and POI in these patients is justified by the preferential expression of a mutant maternal allele in gonads as in other target tissues of peptide hormones acting through the same G-protein-coupled receptor (GPCR)-Gs $\alpha$-cAMP pathway, such as kidney (parathyroid hormone, PTH), thyroid (TSH), and pituitary (GHRH; Mantovani et al. 2002). The mechanism leading to POI should be identical to that seen in $\mathrm{FSH}$ resistance.

\section{Progressive external ophthalmoplegia}

$P O L G$ gene $(\mathrm{MIM} * 174763)$ encodes the DNA polymerase $\gamma$, the enzyme that replicates the human mitochondrial DNA. Mutations in this gene are causative of the autosomal dominant (MIM \#157640) or recessive (MIM \#258450) progressive external ophthalmoplegia (PEO), a disease characterized by weakness of the ocular muscles and fatigue secondary to mitochondrial tissue depletion. It is a genetically heterogeneous disease; dominant POLG mutations cluster in the polymerase $(p o l)$ domain, while the recessive ones affect the proofreading (exonuclease, exo) domain. Luoma et al. (2004) described co-segregation of POI and parkinsonism with POLG pol domain mutations in three families with PEO. The POI manifestations were variable from PA to SA at 44 years of age, frequently anticipating the other manifestations. Two of these families carried the p.Y955C mutation in the highly conserved catalytic polymerase domain, and POI was documented in the extended family. 
The affected men of these families presented with testicular atrophy, suggesting a defect in steroidogenesis, in which the mitochondria have a gatekeeper role. In the third family, the authors reported the POI case of a compound heterozygote for p.N468D in the exo domain and p.A1105T in pol domain mutations. Pagnamenta et al. (2006) described dominantly maternal inherited POI in a three-generation pedigree in association with $\mathrm{PEO}$ and parkinsonism carrying the p.Y955C mutation. This site might be a hotspot for mutations and can lead to mitochondrial DNA depletion, as demonstrated by Southern blot in fibroblasts. On the basis of the early age of onset in comparison with neurological defects, these authors suggested that POLG mutations might also be searched in cases of isolated POI.

\section{Autoimmune polyglandular syndrome type I}

Autoimmune polyglandular syndrome type I (APS1; MIM \#240300) or autoimmune-polyendocrinopathycandidiasis-ectodermal dystrophy (APECED) is an autosomal recessive disorder characterized by the presence of 2/3 major clinical symptoms, including Addison's disease, hypoparathyroidism, and chronic mucocutaneous candidiasis. The onset of manifestations frequently occurs during childhood. Patients with APECED also routinely exhibit a variable number of other autoimmune manifestations, including thyroiditis, type 1 diabetes, ovarian failure, and hepatitis (Paterson \& Peltonen 2005). It was generally considered to be a monogenic disorder; however, more recent analyses have revealed influences of additional genetic loci, in particular the human leukocyte antigen (HLA) complex, on certain disease parameters (Mathis \& Benoist 2007). The autoimmune regulator (AIRE) gene (MIM *607358) was identified as the locus underlying susceptibility to APECED (Finnish-German APECED Consortium 1997, Nagamine et al. 1997), and to date more than 60 variants, including several nonsense and missense variations as well as frameshift ones, were found. Disruption of AIRE protein results in the loss of central tolerance, a process by which developing $\mathrm{T}$ cells with potential reactivity for self-antigens are eliminated during early differentiation in the thymus (Michels \& Gottlieb 2010). APS1 is a rare disorder, but a particular prevalence is seen in Finns, Iranian Jews, and Sardinians (Cervato et al. 2009). In a Finnish survey of 72 patients, hypogonadism was present in $60 \%$ of female patients aged $>12$ years; half of the females with ovarian atrophy failed in pubertal development (Perheentupa 1996). Steroid cell and steroid side-chain cleavage enzyme auto-antibodies in female patients are good predictors of ovarian failure (Falorni et al. 2002).

\section{Ovarian leukodystrophy}

Ovarian leukodystrophy is the name used by Schiffmann et al. (1997) to describe unusual association of POI with vanishing white matter (VWM) disease observed in four patients on magnetic resonance imaging. VWM disease (MIM \#603896) is characterized by slowly progressive neurological deterioration, but the onset is extremely variable including prenatal period until adult age (van der Knaap et al. 2006). In addition, the ovarian insufficiency onset is different among affected females, and it could result in PA or SA. Moreover, the age at onset of neurological degeneration correlated positively with the severity of ovarian dysfunction (Boltshauser et al. 2002). The basic defect of VWM disease is associated with variations in any of the five subunits of eukaryotic translation initiation factor EIF2B. This factor has an important role in protein synthesis and its regulation under different stress conditions, in particular, prevents accumulation of denaturated proteins during cellular stress. Therefore, its dysfunction could be responsible for increased apoptosis of ovarian follicles. In seven patients who presented with POI and ovarian leukodystrophy, eight variants were found in EIF2B2, 4, and 5 (Fogli et al. 2003). To further test the involvement of known mutations in EIF2B genes in POI, 93 patients with POI not associated with leukodystrophy or neurological symptoms have been investigated. None of the known mutations in EIF2B genes, either homozygous or heterozygous, were detected in patients with isolated 46,XX POI (Fogli et al. 2004).

\section{Ataxia telangiectasia}

Ataxia telangiectasia mutated (ATM) gene (MIM *607585) encodes a protein kinase that is involved in cell cycle regulation (Shiloh 2003, Kastan \& Bartek 2004) and is also required for processing the DNA strand breaks that occur during meiosis and immune system maturation, and for maintaining telomere. Mutations in $A T M$ gene generally result in the total loss of the protein (Lakin et al. 1996) and are the underlying causes of ataxia teleangiectasia (AT; MIM \#208900), an autosomal recessive neurodegenerative disorder characterized by uncoordinated movements and ocular telangiectases (Savitsky et al. 1995), chromosome instability, radiosensitivity, immunodeficiency, and a predisposition for cancer. Some patients with AT present ovarian insufficiency due to gonadal hypoplasia with a complete absence of mature gametes (Miller \& Chatten 1967, Boder 1975, Sedgwick \& Boder 1991). The mouse phenotype closely resembles the human phenotype. Atm deficiency in mutant female mice causes lack of primordial and mature follicles and oocytes in extremely small ovaries. Primordial follicles 
seem to degenerate at the time of prophase of meiosis I in gametogenesis, demonstrating a total disruption of meiosis during early stages (Barlow et al. 1996). Several case-control mutation screening studies on the gene have been performed in order to assess the association of ATM mutations and risk of breast cancer (Tavtigian et al. 2009). On the contrary, studies of this gene in 46 ,XX POI cohorts have not yet been performed.

\section{Demirhan syndrome}

Demirhan et al. (2005) reported the case of a 16-year-old girl with acromesomelic chondrodysplasia, genital anomalies, amenorrhea, and hypergonadotropic hypogonadism due to a homozygous variant in the gene coding for bone morphogenetic protein receptor 1B (BMPR1B; MIM *603248). Acrosomelic chondrodysplasias are hereditary skeletal disorders characterized by short stature, very short limbs, and hand/foot malformations. They are caused by homozygous mutations in growth differentiation factor 5 (GDF5), a BMP belonging to the transforming growth factor $\beta$ (TGF $\beta$ ) superfamily, which binds to BMPR1B with high affinity, and plays an essential role in chondrocyte differerentiation (Kornak \& Mundlos 2003). The skeletal phenotype of the patient with $B M P R 1 B$ mutation is similar to that observed in patients with homozygous variations of GDF5 gene, who instead do not have gonadal defects. Mutation analysis of BMPR1B revealed a homozygous 8 bp deletion (del359-366). This mutation is expected to result in a loss-of-function and is thus different from the heterozygous missense mutations in BMPR1B recently shown to cause brachydactyly type A2 through a dominant negative effect (DNE; Lehmann et al. 2003). $B M P R 1 B$ variants can occur naturally also in animals and are found associated with the hyperprolific Booroola phenotype in sheep (Wilson et al. 2001), while female knockout mice present with brachydactyly and infertility (Yi et al. 2001). These findings highlight the dual function of BMPR1B: on one hand in skeletal development as the predominant receptor for GDF5, and on the other and, its role in genital development and ovarian function.

\section{Blepharophimosis-ptosis-epicanthus inversus syndrome}

Blepharophimosis-ptosis-epicanthus inversus syndrome (BPES; MIM \#110100) is an autosomal dominant eyelid malformation characterized by BPES and telecanthus associated (type I) or not associated (type II) with POF. Forkhead transcription factor L2 (FOXL2; MIM *605597) is the only gene currently known to be associated with BPES (Crisponi et al. 2001). These authors pointed out that polled/intersex syndrome in the goat was an animal model of human BPES. Subsequently, the Foxl2 knockout mice were shown to replicate the findings in humans (Schmidt et al. 2004, Uda et al. 2004). The invalidation of Foxl2 expression indeed produced the characteristic cranio-facial alterations, absent upper eyelid, and female-limited infertility with folliculogenesis being blocked at the early stages. Extensive histological studies showed that FOXL2 can be implicated in the squamous to cuboidal transformation of granulosa cells (GCs) and also in the oocyte activation process (Schmidt et al. 2004, Uda et al. 2004). FOXL2 gene encodes a nuclear protein that contains a highly conserved DNA-binding domain and a polyalanine tract of 14 residues, the role of which has not been elucidated yet. More than 125 FOXL2 variants have been described in individuals with BPES types I and II, demonstrating that phenotypic features are caused by the pleiotropic effect of a single gene, rather than by a contiguous gene syndrome. Beysen et al. (2009) recently reviewed a total of 106 unique intragenic FOXL2 mutations identified in 206 unrelated families with BPES of different ethnic origins. Detailed information on most FOXL2 mutations and on affected individuals or families with BPES was made available in the FOXL2 mutation database (http://users.ugent.be/ $\sim$ dbeysen/foxl2). Intragenic mutations represent about $80 \%$ of all genetic defects found in BPES cohorts (De Baere et al. 2003). They include missense changes, frameshift and nonsense mutations, in-frame deletions, and duplications that are distributed along the single exon gene. Genomic rearrangements, comprising deletions encompassing FOXL2 entire gene or located outside its transcription unit, represent 12 and $5 \%$ of all genetic defects respectively (Beysen et al. 2005).

A genotype-phenotype correlation for intragenic mutations was proposed: mutations predicted to result in proteins with truncation before the poly-Ala tract might be associated with BPES type I, whereas poly-Ala expansions might rather lead to BPES type II. These correlations were based on the classification of intragenic mutations into seven groups according to their effect on the predicted protein that is likely to be produced (De Baere et al. 2003). A recent model of FOXL2 protein proposed that mutants can be sorted into two classes: those that potentially alter protein-protein interactions and those that might disrupt the interactions with DNA (Nallathambi et al. 2008).

It was also shown that the steroidogenic acute regulatory $(S T A R)$ gene, whose protein is a marker of GC differentiation, is a direct target of FOXL2, acting as a repressor of STAR. Two disease-associated truncating variations of FOXL2 (truncation of 93 and 218 amino acids) did not result in complete loss of repressor activity. In addition, these FOXL2 truncated proteins were shown to exhibit a DNE, whereas several mutants led to a loss-of-function protein. It was concluded that 
the entire alanine/proline-rich carboxyl terminus is important for the repressor activity of FOXL2, and that truncating mutations may preferentially lead to BPES and ovarian dysfunction by accelerated differentiation of GCs and secondary depletion of the primordial follicle pool (Pisarska et al. 2004).

Poly-Ala expansions preferentially lead to BPES type II; however, this view has been challenged by several reports. Raile et al. (2005) described a 16-year-old girl who was thought to have BPES type I with the poly-Ala expansion c.667_702dup (p.A221_A234dup) and had an extremely large corpus luteum cyst that caused transient ovarian dysfunction. Although it was postulated that this transient ovarian insufficiency might be caused by malfunction of the FOXL2 protein, this possibility may be unlikely, as the ovarian dysfunction seen in BPES type $I$ is generally irreversible. Nallathambi et al. (2007) reported the first case with a positive correlation between the size of the poly-Ala expansion, its dosage, and the penetrance of the BPES phenotype in a consanguineous Indian family, within which a novel homozygous expansion of 19 Ala residues in FOXL2 was associated with a recessive form of BPES with ovarian dysfunction. Méduri et al. (2010) recently described two patients carrying two different heterozygous poly-Ala expansions of the FOXL2 protein associated with the typical eyelid defects and variable degrees of ovarian dysfunction (from PA to SA). The cases described here emphasize the importance of long-term clinical follow-up of ovarian function also in patients with a poly-Ala expansion.

FOXL2 was also suggested as a possible candidate gene also for nonsyndromic POI (Crisponi et al. 2001, Prueitt \& Zinn 2001). Recently, the first functional study supporting a role of FOXL2 mutations in nonsyndromic POI was reported (Laissue et al. 2009). A novel FOXL2 missense mutation p.G187N was found in a case of POI without BPES. The subcellular localization of the mutant protein was normal, but its transactivation capacity tested on two reporter promoters, specific for the ovary, was significantly lower than that of normal FOXL2. However, the mutant protein was found to strongly activate a reporter construct driven by the $O s r 2$ promoter, a gene assumed to be a craniofacial target of FOXL2, compatibly with the absence of BPES in the patient. Other studies rarely found or failed to find FOXL2 sequence variants in POI cases without BPES (De Baere et al. 2001, 2002, Harris et al. 2002, Bodega et al. 2004, Gersak et al. 2004, Laissue et al. 2009).

\section{Nonsyndromic POI}

Genetic forms of isolated POI can be suspected in women with 46,XX karyotype (Simpson 2008). They can have different modes of inheritance mainly depending on the location of the gene involved. In general, defects in autosomal genes follow a recessive mode of inheritance, whereas the inheritance of the defects in $\mathrm{X}$-linked genes may be dominant through maternal lineage or may be transmitted by a male carrier.

\section{Fragile $\mathrm{X}$ mental retardation 1}

The fragile $\mathrm{X}$ mental retardation 1 (FMR1; MIM *309550) gene is located at Xq27.3 and is responsible for the fragile $\mathrm{X}$ syndrome, a form of $\mathrm{X}$-linked mental retardation, when the CGG trinucleotide in the $5^{\prime}$-untranslated region of the gene is expanded over 200 repeats (full mutation). The premutated allele contains expansions between 55 and 199 repeats that can further expand to full mutation in one generation (Allen et al. 2007). Women with FMR1 premutations, but not full mutations, have an increased likelihood of developing POI (Allen et al. 2007). The prevalence of POI in women with premutated alleles is estimated around $16 \%$, with a relative risk of $16 \%$ (Wittenberger et al. 2007). Premutation carriers have been identified in $0 \cdot 8-7 \cdot 5 \%$ of women with sporadic form of POI and in up to $13 \%$ of women with familial forms. Interestingly, the association of repeat size with POI risk is nonlinear, as the risk appears to be higher between 79 and 99 repeats, and the risk appears to be much reduced for women with repeat sizes between 55 and 78 and over 100 (Allen et al. 2007, Wittenberger et al. 2007). Large repeats size between normal ( $<40$ repeats) and premutation repeats that is termed intermediate or 'gray zone' (41-54 repeats) exists. Two studies have also reported an increased risk of POI for women with a 'gray zone' size repeats (Bretherick et al. 2005, Bodega et al. 2006). However, a recent English study failed to replicate these previous studies, despite a significantly larger sample size (Bennett et al. 2010). A possible explanation of the association between ovarian insufficiency and the premutation state of FMR1 gene is that the transcription from premutated alleles is significantly increased (Loesch et al. 2007). Repeats between 55 and 79 may, on one hand, lead to an increased production of fragile $\mathrm{X}$ mental retardation protein (FMRP), an RNA-binding protein regulating the translation of a subset of mRNAs through a suppression mechanism (Jin \& Warren 2000). Since FMRP is highly expressed in germ cells of the fetal ovary (Rifé et al. 2004), the accumulation of FMRP may impair the expression of genes required for oocyte development. Longer repeats may instead be translated less efficiently. Since FMR1 expression was also seen in GCs of maturing follicles (Hergersberg et al. 1995), accumulation of abnormal FMR 1 mRNAs may alternatively have long-term toxic effect favoring follicle atresia (Tassone et al. 2000). This mechanism is well supported for the other known premutation-associated disorder, FXTAS 
(Oostra \& Willemsen 2003). Screening for fragile X premutations is recommended for the routine work-up for any woman presenting with POF. The reason for this is that women with POF have an $\sim 5 \%$ chance of conceiving, and this possibility may be even higher in the premutation subgroup. Women need to be informed if they are at risk of having a child with fragile $\mathrm{X}$ syndrome. In addition, the identification of a family in which the fragile $\mathrm{X}$ repeat site is expanded can lead to the identification of other female family members at risk either of transmitting fragile $\mathrm{X}$ syndrome or of POI. The identification of an index case should therefore trigger genetic counseling throughout the pedigree (Conway et al. 1996).

\section{Ligands of TGF $\beta$ (TGF $\beta$ superfamily)}

Several members of TGF $\beta$ superfamily are expressed in the ovarian follicle, either by the oocyte or by GCs (Shimasaki et al. 2004). These factors are known to promote growth and differentiations (GDFs) in the tissues where they are expressed and include either GDFs, BMPs, as well as inhibins, activins, or AMH. TGF $\beta$ s are commonly translated as pre-pro-proteins. The pro-region typically regulates posttranslational processing and dimerization of mature peptide forming either hetero- or homo-dimeric proteins that finally exert the biological activity at the target cell. The follicular paracrine action of several of these factors has been shown to be required for correct folliculogenesis, and the encoding genes have been investigated in the case of POI.

\section{Bone morphogenetic protein 15}

BMP15 gene (MIM *300247) encodes an oocyte-derived growth and differentiation factor, which is involved in follicular development as a critical regulator of many GC processes (Dube et al. 1998, Chang et al. 2002, McNatty et al. 2004, Shimasaki et al. 2004).
As other TGF $\beta$ s, $B M P 15$ gene encodes a pre-pro-protein consisting of a signal peptide, a pro-region and a mature domain that can form homo- or hetero-dimers with related factors, such as GDF9 (Chang et al. 2002; Fig. 2). The main roles of BMP15 include a) the promotion of follicle maturation since the primordial gonadotropinindependent phases of folliculogenesis; b) regulation of follicular GC sensitivity to FSH action; c) prevention of GC apoptosis; d) promotion of oocyte developmental competence; and e) regulation of ovulation quota (Shimasaki et al. 2004, Hashimoto et al. 2005, Hussein et al. 2005, 2006, Fabre et al. 2006). The relevance of BMP15 action in ovarian folliculogenesis was initially shown by experimental and natural models. All together, the data so far collected in different mammalian species indicate that the role of BMP15 may be more critical in mono-ovulating species (such as sheep and human) than in the poly-ovulating ones (mice). Experimental disruption of Bmp15 gene in mice causes a mild fertility defect limited to females (Yan et al. 2001), whereas natural missense mutations in several strains of ewes cause a hyperprolificacy phenotype in the heterozygous state (increased litter size to three to five lambs per litter against one in wild type) and a female infertility with complete block of folliculogenesis in the homozygous state (FecX factors; Galloway et al. 2000, Davis 2004, Hanrahan et al. 2004, McNatty et al. 2005, Bodin et al. 2007). BMP15 maps to a locus on the short arm of X chromosome (Xp11.2) within a 'POF critical region' where several of the TS traits are located including ovarian failure (Zinn et al. 1998, Persani et al. 2009). In humans, mutations in BMP15 gene have been found in association with both PA and SA in several worldwide POI cohorts with a variable prevalence between 1.5 and $12 \%$ (Table 2). The first heterozygous mutation in BMP15 gene (p.Y235C) was reported by us in two Italian sisters with hypergonadotropic ovarian failure characterized by PA and ovarian dysgenesis, who inherited the genetic alteration from the unaffected father (Di Pasquale et al. 2004). This mutation was

Table 2 Frequency of BMP15 gene variants in patients with primary ovarian insufficiency (POI) and controls of different ethnicity

\section{Size of $\quad \begin{aligned} & \text { Patients with } \\ & \text { nonsynonymous Size of control }\end{aligned}$ POI cohort variations (\%) population}

\begin{tabular}{lrl} 
Origin & & \\
Japan & 15 & 0 \\
New Zealand & 38 & 0 \\
Europe and USA (Caucasian) & 166 & $4 \cdot 2^{\mathrm{a}}$ \\
Europe and North Africa & 203 & $1 \cdot 5^{\mathrm{a}}$ \\
India & 202 & $8 \cdot 9^{\mathrm{a}}$ \\
Italy and USA (Caucasian) & 300 & $4 \cdot 3^{\mathrm{a}}$ \\
China & 100 & $6^{\mathrm{a}}$ \\
Europe, North Africa and Asia & 50 & $12^{\mathrm{a}}$ \\
& & \\
\cline { 2 - 2 } & &
\end{tabular}

www.endocrinology-journals.org
Takebayashi et al. (2000) Chand et al. (2006) Di Pasquale et al. (2006) Laissue et al. (2006) Dixit et al. (2006a) Rossetti et al. (2009) Wang et al. (2010)

Tiotiu et al. (2010) 
located in a residue highly conserved among species and generated aberrant high-molecular weight products in vitro as observed by western blot performed in nonreducing conditions, a likely consequence of the additional Cys in the pro-region. A bioassay on primary cultures of human GCs showed an impairment of the growth stimulatory activity of recombinant mutant BMP15 in comparison with wild-type protein. Co-incubation experiments of wild-type and p.Y235C proteins were consistent with a DNE exerted by mutant on the stimulatory activity of wild-type protein on GCs (Di Pasquale et al. 2004; Fig. 3). Afterward, other variants were identified with variable frequency in patients from Europe, USA, North Africa, India, China, and Asia (Di Pasquale et al. 2006, Dixit et al. 2006a, Laissue et al. 2006, Rossetti et al. 2009, Tiotiu et al. 2010, Wang et al. 2010; Fig. 4 and Table 2). Almost all of these are missense variations found in the heterozygous state. These variations are also located in the gene sequence encoding the pro-region of the protein. More recently, we studied the recombinant products of several of these missense variations and showed an impaired amount of mature BMP15 protein produced by variant vectors in comparison with wild type, suggesting a hampered processing. Consistently, we showed a significant reduction in their biological effects by using a novel BMP-responsive luciferase-reporter assay on a human GC line (Rossetti et al. 2009). Co-transfection of equal amounts of wild-type plasmids failed to completely restore the normal transcriptional activity. Since a reduced production of bioactive proteins was observed by western blot, we interpreted these results as consistent with a mechanism of haploinsufficiency similar to that described for the mutations found in sheep. Among all the identified variations, only one was found to cause a premature truncation. This truncated variant created a premature stop in the pro-region (p.E211X), resulting in the complete lack of mature BMP15 peptide, and was found in an Indian woman with PA and ovarian dysgenesis (Dixit et al. 2006a). Very recently, a Chinese group has reported the first missense substitution (p.R329C) located in the region of the mature peptide that, involving an Arg to Cys amino acid change, could alter the structure of BMP15 by impairing the correct folding of the protein (Wang et al. 2010). This variant co-segregated with POF phenotype in mother and daughter. To date, only two studies failed to find an association between BMP15 mutations and

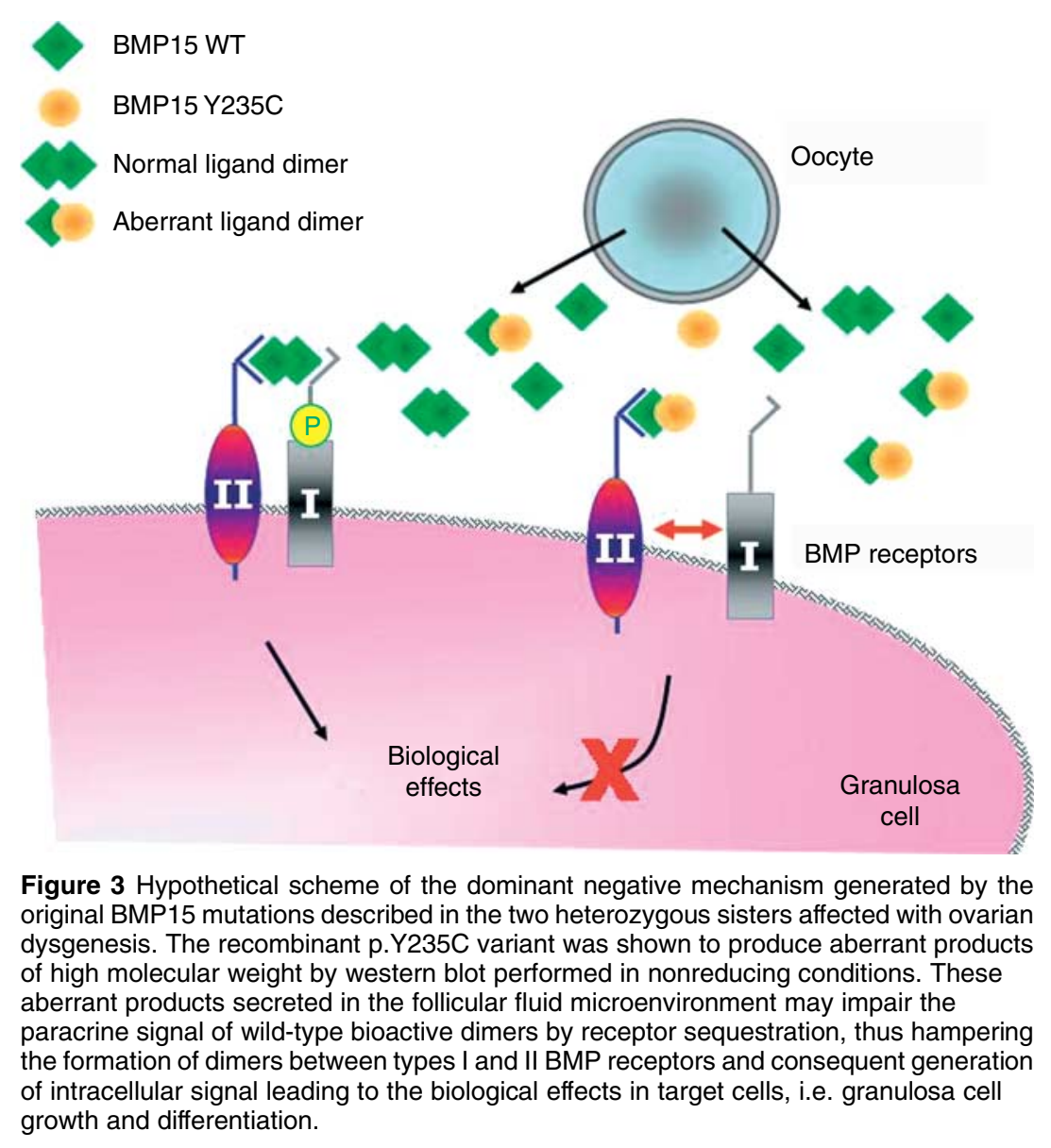




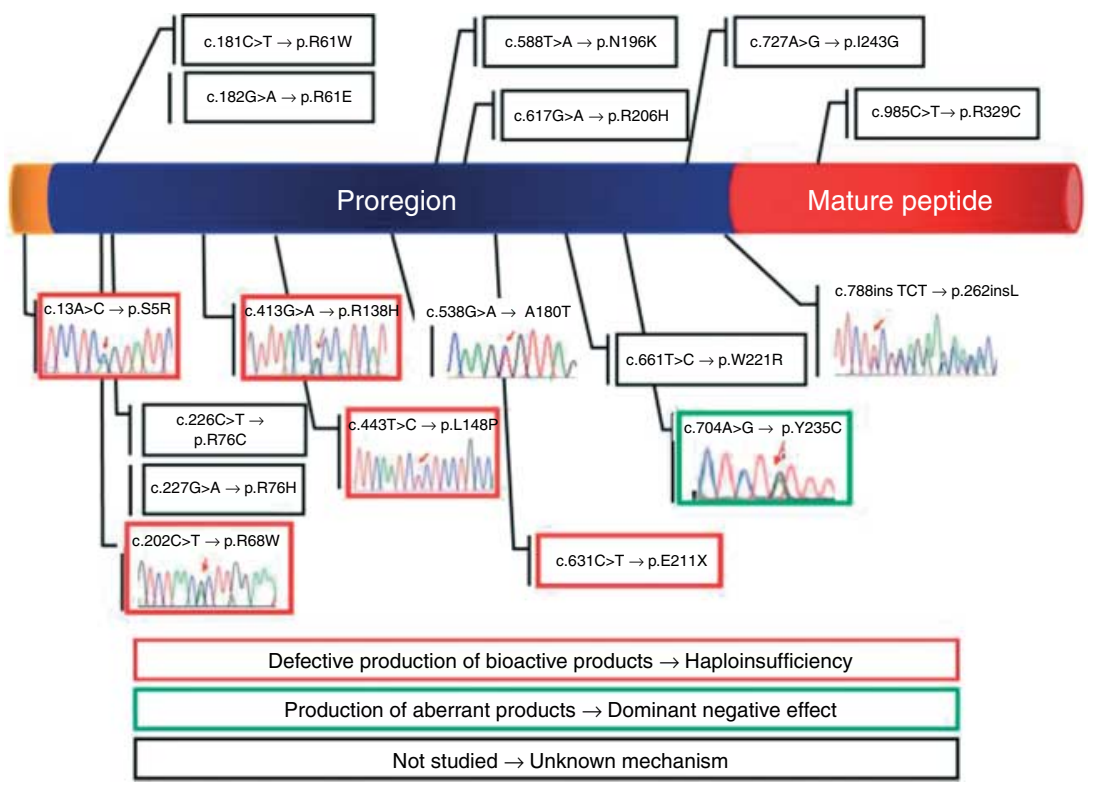

Figure 4 Schematic illustration of the known BMP15 variants that have been detected in POI patients. The specific electropherograms of the variations identified by our group are reported. The different colored boxes show the potential biological mechanisms involved by the variants tested in vitro by Di Pasquale et al. (2004) and Rossetti et al. (2009). The two variants not enclosed in a box did not display any functional defect in vitro and should probably be considered missense variations with modest or no biological effect (Rossetti et al. 2009). The biological impact of the first variation in the mature peptide is presently unknown.

POI: a Japanese group (Takebayashi et al. 2000) and a group from New Zealand (Chand et al. 2006), which reported the absence of BMP15 mutations in a series of women with SA. One possible explanation for these negative results may be the small size of the cohorts studied (15 and 38 POF patients respectively). Importantly, some of the missense variations in BMP15 gene have also been found at low percentages in the control populations (see Table 2 for details), a finding that may question or diminish their pathogenic role. In light of these findings, one could hypothesize that BMP15 variations might play a predisposing role in a context of POI considered as a complex multifactorial disorder, in contrast to the view of POI as a monogenic disorder. However, before drawing conclusions, it must be emphasized that the correct control population of these studies should be represented by women of the same ethnicity and with proven physiological menopause beyond the age of 50 years. Unfortunately, both these conditions were not met in most of the studies reporting BMP15 variants, as opposed to the studies designed by our group (Di Pasquale et al. 2006, Rossetti et al. 2009).

The functional mechanism by which BMP15 variants with a proven biological impact may disturb ovarian folliculogenesis is presently unknown. We may envisage that a diminished BMP15 paracrine signal in the follicle would involve an impairment of the anti-apoptotic effects on GCs, a mechanism then favoring follicle atresia. Alternatively, BMP15 variants may finally result in an altered recruitment of pre-antral follicles by gonadotropins. For this reason, BMP15 gene has also been investigated in patients with opposite alterations of ovulation mechanism, and no linkage was found either in patients with polycystic ovaries or in mothers with spontaneous dizygotic twinning (Zhao et al. 2008a,b). Indeed, further studies are needed to understand the exact role of BMP15 variants in POI pathogenesis. Interestingly, all the findings described here for several human variants might also suggest $B M P 15$ as the first X-linked gene whose haploinsufficiency may play a determinant role for the generation of ovarian dysgenesis in TS, as hypothesized earlier by others (Layman 2006).

\section{Growth differentiation factor 9}

Besides BMP15, other TGF $\beta$ family members have a relevant role in the progression of folliculogenesis. Among them, GDF9 (MIM *601918) is the homologous gene of BMP15 (also named GDF9b). GDF9 is also expressed in the oocyte and its products can form noncovalent heterodimers acting in a synergistic manner on the function of surrounding follicular GCs (Yan et al. 2001). From experimental animals, it was 
observed that GDF9 function is more critical in poly-ovulating species such as mice where GDF9 is required for folliculogenesis (Dong et al. 1996). Natural GDF9 gene mutations with ovarian effects similar to those seen in BMP15 mutants were also detected in Cambridge and Belclare sheeps (Hanrahan et al. 2004). GDF9 was shown in vitro to stimulate cumulus expansion, with the induction of hyaluronan synthase 2, cyclooxygenase 2, and STAR protein (Elvin et al. 1999). GDF9 can therefore be considered a candidate gene for human POI. The first mutational screening of the GDF9 gene was reported in 15 Japanese women with premature ovarian insufficiency, but no mutations were found (Takebayashi et al. 2000). Following this first study, a more extensive number of POI patients $(n=629)$ have been screened for mutations in the coding region of the GDF9 gene. GDF9 gene variations in humans described so far in different ethnicity (p.K67E; p.V216M; p.S186Y; p.P103S; and p.T238A) are all heterozygous, affect exclusively the pro-region with a prevalence of $1.4 \%$, and are not detected in the control samples (Dixit et al. 2005, Laissue et al. 2006, Kovanci et al. 2007, Zhao et al. 2007). Some studies, however, failed to identify possible deleterious variants suggesting a rare contribution of GDF9 gene variations in those populations (Chand et al. 2006, Wang et al. 2010). Some rare insertion/deletion and missense variations in GDF9 gene have also been associated with spontaneous dizygotic twinning; the reported frequency of these variants is around $4 \%$ confirming a possible role of this factor in the determination of ovulation quota also in humans (Montgomery et al. 2004, Palmer et al. 2006).

\section{Inhibin A}

Inhibin is another candidate gene for mutational studies in humans, given its important role in regulating ovarian function either as a negative modulator of pituitary FSH synthesis or as a paracrine factor. Inhibin A $(I N H A)$ gene knockout mice lack the bioactive inhibin dimers thus resulting in raised FSH levels, infertility, and sex chord stromal tumors at an early age with nearly $100 \%$ penetrance, demonstrating that inhibin functions in vivo as a tumor suppressor in the gonads of mice (Matzuk et al. 1992). In a subsequent work, Matzuk et al. (1994) showed that INHA-KO mice eventually developed adrenal cortical sex steroidogenic tumors with nearly $100 \%$ penetrance, demonstrating that inhibin is also a tumor suppressor for the adrenal gland. The first evidence of a genetic association between inhibin and POI came forth from a POI patient with the translocation 46,XX,t (2;15) (q32.3; q13.3). The translocation breakpoint on chromosome 2 paved interest in the INHA (MIM *147380) subunit locus (2q33-36), therefore further investigations are required for the mutational screening of this gene (Burton et al. 2000). One missense variation of INHA gene (p.A257T) has been associated with POI in several populations (Shelling et al. 2000, Marozzi et al. 2002, Dixit et al. 2004), with a prevalence of $0-11 \%$ depending on the ethnicity of the population studied. In fact, the highest frequency of INHA variant was found in the Indian population (Dixit et al. 2004, 2006a, Prakash et al. 2010) and in the New Zealand study, including Slovenian patients (Shelling et al. 2000). An Italian study reported a significant association between the INHA p.A257T variant and sporadic $(4.5 \%)$ and familial POI cases (7.7\%; Marozzi et al. 2002). However, the study has been recently replicated in a larger cohort of Italian and German subjects, and no differences in variant frequency were detected between POI cases and controls (Corre et al. 2009). The INHA variation is also rare in populations from Argentina (Sundblad et al. 2006) and Korea (Jeong et al. 2004). Nevertheless, a recent meta-analysis of the random effects on the risk of POI in carriers of the INHA variant from the most relevant studies revealed a combined risk difference of $0.04(-0.03$ to $0 \cdot 11)$ with $95 \%$ confidence interval (Chand et al. 2010). Based on these, it is plausible that the INHA variant allele might confer a susceptibility to develop POI. This view may also be confirmed by the functional study demonstrating a reduced bioactivity of INHA variant in the inhibition of a inhibin-reporter in mouse L $\beta$ T2 pituitary gonadotrope cells, while variable results were obtained when the reporter was expressed in COV434 GCs line; interestingly, dimerization with $\beta$-subunits was unaffected by the variation (Chand et al. 2007). Moreover, two promoter variations (c. $-16 \mathrm{C}>\mathrm{T}$ and c. $-124 \mathrm{~A}>\mathrm{G}$ ) were also reported as additional mechanisms potentially affecting the transcriptional regulation of INHA gene and predisposing to POI. However, the association with POI never reached the statistical significance in all the populations studied (Marozzi et al. 2002, Harris et al. 2005, Corre et al. 2009, Woad et al. 2009). In humans, no variations were ever found in the inhibin $\beta A$ or $\beta$ B subunit.

\section{G-protein-coupled receptors}

\section{Gonadotropin receptors}

FSHR and LHR are glycoprotein hormone receptors belonging to the GPCRs family (Themmen \& Huhtaniemi 2000). Together with their binding hormones, LH and FSH, these receptors are essential for normal reproductive function in both sexes. Lossof-function mutations affecting these receptors cause gonadotropin resistance with hypergonadotropic hypogonadism. However, such mutations are extremely rare. A linkage analysis in a Finnish population 
revealed a significant association between a locus on 2p21 and ovarian dysgenesis. This locus contains both the genes encoding FSHR and LHR, and following the sequencing of the entire FSHR gene (MIM *136435) revealed a homozygous missense mutation that determines the p.A189V substitution in the extracellular domain of the receptor (Aittomaki et al. 1995). This type of POF follows a classic recessive transmission with homozygous female carriers affected by PA and ovarian dysgenesis. From in vitro studies, it was observed that this mutant receptor has an altered folding and is retained inside the cells failing to reach the plasma membrane, likely due to an impaired glycosylation, thus causing a complete FSH resistance (Aittomaki et al. 1995, Rannikko et al. 2002). The p.A189V mutation appears to be particularly frequent only in the Finnish population, and it was not found in most other populations, suggesting a founder effect (da Fonte Kohek et al. 1998, Jiang et al. 1998, Layman et al. 1998, Loutradis et al. 2006, Prakash et al. 2009). Ghadami et al. $(2008,2010)$ succeeded in restoring FSH responsiveness in various cell lines expressing the mutated FSHR through the transfection of the normal human FSHR gene carried by an adenovirus vector and, very recently, also in the $\mathrm{FSHR}^{-/-}$mouse. These are the first attempts to develop a gene therapy approach for this type of ovarian failure. Other mutations in different regions of the FSHR gene have nowadays been reported in women with the classic biochemical phenotype of POI (FSH higher than LH levels). Complete FSH resistance is associated with absent pubertal development, and PA and partial forms are characterized by postpubertal POI and SA. All mutations in the extracellular domain generally impair the targeting of the receptor to the plasma membrane, thus affecting the ligand binding; in contrast, mutations in the transmembrane domain partially impair the transduction of the stimulatory hormone signal (Beau et al. 1998, Touraine et al. 1999, Doherty et al. 2002, Allen et al. 2003, Nakamura et al. 2008).

Biallelic inactivating variants of the $L H R$ gene (MIM +152790 ) are a rare cause of POI in 46 , XX women. They represent a particular form of the disease characterized by LH levels higher than those of FSH. Evidence for a particular phenotype of ovarian insufficiency in women with LH resistance was obtained by the pedigree studies of males affected with Leydig cell hypoplasia (Latronico et al. 1996, 1998). Differently from male patients, the degree of LH resistance must be severe to cause the POI phenotype, which is in general characterized by oligoamenorrhea or SA with evidence of multiple antral follicles by ultrasound. Ovarian biopsies reveal all stage of follicular development until the pre-ovulatory stage, but typically ovulation fails to occur.

\section{G-protein-coupled receptor 3}

The oocyte-specific GPR3 (MIM *600241) gene is essential in maintaining meiotic arrest in mammalian oocytes (Mehlmann et al. 2004). Disruption of GPR3 in the knockout mouse determines LH-independent resumption of meiosis resulting in early depletion of oocytes and thus premature ovarian aging (Ledent $e t$ al. 2005). To determine whether mutations in the GPR3 gene were associated with POI, Kovanci et al. (2008) performed a mutational screening in 82 North American Caucasian women with POF, but none showed perturbations of significance. Recently, another study screened the coding region of GPR3 in 100 Chinese POI patients for variants of the GPR3 gene. As in the previous study, no perturbations were found in the coding region (Zhou et al. 2010). The results of these studies suggest that mutations in GPR3 are not a common explanation for POI.

\section{Nuclear proteins}

\section{NR5A1}

NR5A1 (MIM + 184757) gene, also termed steroidogenic factor 1 or fushi tarazu factor (Drosophila) homolog 1, encodes a nuclear receptor expressed in bipotential gonads since early human embryonic development. NR5A1 is a key transcriptional regulator of genes involved in the hypothalamic-pituitarysteroidogenic axis (Luo et al. 1994), including STAR, CYP11A1, CYP17A1, CYP19A1, LH/CGR, and INHA. Until 2008, 18 mutations of NR5A1 were described in cases of 46,XY disorders of sex development (DSD), with or without adrenal failure (Achermann et al. 1999, Lin et al. 2007). Recently, a key role for this factor in ovarian development and function as well has been evidenced. In fact, further 19 mutations in the gene, including in-frame deletions, missense, and frameshift mutations, were detected in members of four families with histories of both 46,XY DSD and 46,XX POI and also in 2/25 women with isolated ovarian insufficiency but in none of the 700 control alleles (Lourenço et al. 2009). Mutations were associated with a range of ovarian anomalies, including gonadal dysgenesis with PA or SA. Functional analysis revealed that each mutant protein had altered transactivational properties in gonadal promoters important for follicle growth and maturation. Such transcriptional disorder in the ovary would then lead to altered folliculogenesis and ovarian insufficiency (Bashamboo \& McElreavey 2010).

\section{Other transcription factors}

The family of forkhead transcription factors comprises over 100 members involved in several developmental processes, including the mediation of TGF $\beta$ 
superfamily signals by binding to members of the SMAD family proteins (Attisano et al. 2001). Similar to FOXL2, a small subfamily of forkhead transcription factors consisting of FOXO3a (MIM *602681), FOXO1a (MIM *136533), and FOXO4 (MIM *300033) has been shown to have a key role in ovarian function. Foxo3a knockout female mice exhibit a marked age-dependent decline in reproductive fitness due to a premature follicular development leading to oocyte death and early depletion of follicles, which results in infertility (Castrillon et al. 2003). In contrast, the constitutive expression of Foxo $3 a$ in the oocytes of transgenic mice leads to a delayed follicular development and oocyte growth, in the end causing infertility. Furthermore, constitutive expression of Foxo3a determines a significant reduction in BMP15 expression, suggesting a regulatory action of FOXO3a on this factor (Liu et al. 2007). The ovarian phenotype of mouse models resembles the human POI phenotype, thus suggesting that FOXO3a could be a candidate gene for POI in women. The first mutation screening in POI patients revealed two potentially pathogenic variations that were absent in controls (p.S421L and p.R506H) in 2 out of 90 POI cases from New Zealand and Slovenia (2.2\%; Watkins et al. 2006). A subsequent analysis on 50 patients of a French cohort identified only one amino acid substitution (p.Y593S) probably with no deleterious impact on protein function (Vinci et al. 2008). The sequencing of FOXO1a gene in 90 POI patients showed no association with the ovarian phenotype (Watkins et al. 2006), but it should be necessary to extend the study of this gene to a larger panel of POI patients. FOXO4 gene maps at Xq13.1 (MIM *300033), and it has been demonstrated to be a potent regulator of cell cycle, but no linkage has been established so far with POI.

Since animal models affected by a disrupted expression of meiotic genes showed a rapid depletion of germ cells in the ovaries, a recent study investigated whether variations in such genes may be associated with POI (Mandon-Pépin et al. 2008). The authors analyzed genes involved in meiosis, such as DMC1 (MIM *602721), MSH4 (MIM *602105), MSH5 (MIM *603382), and SPO11 (MIM *605114). The sequencing of genomic DNA from 41 POI women led to the identification of a single heterozygous missense substitution (p.P29S in MSH5) in two Caucasian women. This variant was not found in 36 controls. Another POI patient of African origin showed a homozygous change in DMC1 gene (p.M200V). This study needs further confirmation in larger cohorts of patients and controls and functional studies evaluating the functional activity of the variants. However, MSH5 and DMC1 variations may be an additional, and probably obvious, explanation for POI.
Among other obvious candidates, two additional transcription factors may be included. Newborn ovary homeobox (NOBOX; MIM *610934) and factor in germline alpha (FIGLA; MIM *608697) encode two oocyte-specific transcription factors that regulate genes unique to oocytes. NOBOX is a homeobox gene that is critical for specifying an oocyte-restricted gene expression pattern including Mos, Oct4, Rfpl4, Fgf8, Zar1, Dnmt1o, Gdf9, Bmp15, and H1oo transcripts (Rajkovic et al. 2004). Nobox deletion in knockout mice accelerates postnatal oocyte loss with follicles replaced by fibrous tissue resulting in a phenotype similar to nonsyndromic ovarian failure in women. Causative mutations in this gene have been investigated recently in several populations. A novel missense variant (p.R355H), which disrupts the binding of the NOBOX homeodomain to DNA, has been reported in a small subset (1 of 96) of Caucasian POI patients from the United States (Qin et al. 2007); however, two other studies failed to find causative mutations in Japanese and Chinese series (Zhao et al. 2005, Qin et al. 2009), suggesting that mutations in the homeobox domain of NOBOX may be uncommon explanations for POI in Asiatic populations. FIGLA is a basic helix-loop-helix transcription factor that regulates the expression of zona pellucida genes. Female Figla ${ }^{-/-}$mice show rapid oocytes loss after birth and no primordial follicles formation. The ovarian phenotype in knockout mice thus suggested that FIGLA variations might contribute to human POI. To date, the only mutational study evaluating FIGLA gene in women with POF identified two heterozygous deletions in two unrelated cases among 100 Chinese POI subjects. These variants were not detected among 304 ethnically matched controls. Molecular analyses showed that these variants may indeed have a pathogenic role. One deletion leads to a premature truncation of the peptide sequence lacking the functional domains (p.G6fsX66), and may thus contribute to the ovarian defect by a mechanism of haploinsufficiency. In contrast, the other deletion leads to the loss of one residue (p.140delN), and in vitro studies showed an altered heterodimerization of mutant FIGLA with other partner nuclear transcription factors, thus suggesting a potential DNE mechanism leading to POF (Zhao et al. 2008a,b).

\section{Progesterone receptor membrane component 1}

Progesterone receptor membrane component 1 (PGRMC1; MIM *300435) gene was recently described as a new candidate gene, thanks to the finding of an $\mathrm{X} /$ autosome translocation in a mother and daughter both diagnosed with POI that maps within the $\mathrm{X}$ 'critical region' for POF at Xq13-26. The subsequent screening of the entire gene has been performed on a cohort of 67 women with idiopathic POI and revealed 
one sporadic patient who was heterozygous for a single missense substitution (p.H165R) located in the intracellular C-terminus, within a domain that is essential for the nontranscriptional regulation of cytochrome P450. The missense variation of PGRMC1 would impair the anti-apoptotic action of progesterone in the developing ovary resulting in the premature loss of ovarian follicles and, ultimately, in ovarian insufficiency (Mansouri et al. 2008).

\section{The genome-wide approach to POI}

An alternative approach for novel POI candidate genes finding is the genome-wide analysis. This approach can be divided in analysis of linkage and in genome-wide association studies (GWAS). In linkage analysis, genetic loci that contribute to a trait can be identified using a set of genetic markers (microsatellites) in related individuals. The overall incidence of familial cases of POI is reported to range 4-31\% (Cramer et al. 1995, Torgerson et al. 1997, Vegetti et al. 1998). However, due to the rarity of pedigrees with a large enough number of patients available for analysis, few linkage analyses have been performed so far. Oldenburg et al. (2008) performed a genome-wide linkage analysis on a relatively large Dutch family with POI, showing a dominant pattern of inheritance, with complete penetrance and possible anticipation, given that the subsequent generations developed POI at an earlier age. The authors identified a region on chromosome 5q14.1-q15, which revealed several genes expressed in the ovary with a possible role in pathways related to ovarian failure.

In contrast, GWAS investigate genetic variations in unrelated affected individuals compared to matched controls by means of $500 \mathrm{k}-1 \mathrm{M}$ single nucleotide polymorphisms (SNPs) not chosen on the basis of their possible functional effect. Since the publication of the International HapMap Consortium (2005), a public database containing frequent genetic variants $(\geq 1 \%)$, GWAS in population-based POI cases are beginning to emerge. In a two-stage association study in a Korean population (101 cases and 87 controls), Kang et al. (2008) showed for the first time a strong association of PTHB1 gene (MIM *607968) with POI $(P<0 \cdot 001)$. PTHB1 was first identified in osteoblastic cells, where its expression is downregulated early in response to PTH exposure. It has been identified in other tissue, but not in the ovary, and its physiological function remains unknown. Interestingly, PTHB1 variants have been described in a subset of patients with Bardet-Biedl syndrome (MIM \#209900), a heterogeneous disease characterized by variable manifestations, including retina, kidney, liver abnormalities, mental retardation, polydactyly, obesity, and sometimes POI and genitourinary defects in females. This study may suggest PTHB1 as a novel susceptibility gene for POI.
A genome-wide significant association was observed in another study on a small Caucasian POI population (99 unrelated cases and 235 controls) for the SNP rs246246 (allele frequency $P=6 \times 10^{-7}$ ), which mapped to an intron of ADAMTS19 (MIM *607513; Knauff et al. 2009). This gene encodes a zinc-dependent metalloprotease and is known to be upregulated in the female mouse gonads during sexual differentiation. However, replication in an independent Dutch cohort (60 POI cases and 90 controls) could not confirm a clear association $\left(P=4 \cdot 1 \times 10^{-5}\right.$ in a joint analysis; Knauff et al. 2009). These authors did not observe strong evidence for any of the 74 selected $P O F$ candidate genes or linkage regions being previously associated with idiopathic POI in Caucasian females. Nevertheless, suggestive association $(P<0 \cdot 005)$ was observed for SNPs that mapped in BDNF, CXCL12, LHR, USP9X, and $T A F 4 B$, all possible candidate genes on the basis of animal models showing POI or POI-like phenotype (Knauff et al. 2009). However, these GWAS have several limitations. Replications in independent cohorts are needed, as the presence of false positives resulting by chance is due to the general small size of these studies. GWAS would therefore require thousand cases and controls to be genotyped to obtain a significant statistical power. Moreover, there may be particular problems beyond mere statistical association to identify the functional basis of the link between a genetic variant and a complex trait, such as the onset of premature menopause.

Finally, in addition to linkage analysis and GWAS based on SNPs, there is increasing interest toward the association of structural variants (deletions, insertions, and copy number variations, $\mathrm{CNVs}$ ) with complex traits.

An array comparative genomic hybridization (a-CGH) analysis for the research of CNVs has been recently performed for the first time on 99 Caucasian POI women, with PA $(n=33)$ or SA $(n=66)$ of sporadic or familial (20\%) origin, and led to the identification of 31 CNVs spread over the genome. The authors reported eight statistically significantly different CNVs, and, among them, they identified two genes to be involved in reproductive disease (DNAH5 and NAIP), two genes in reproductive endocrinology (DUSP22 and NUPR1), and one gene in folliculogenesis (AKT1), which could represent new putative candidate gene associated with POI (Aboura et al. 2009). Very recently, Quilter et al. (2010) reported an a-CGH study on 42 idiopathic cytogenetically normal POF patients in order to detect cryptic CNVs of the X chromosome. The new data reported in this study might reveal further discrete $\mathrm{X}$ chromosome intervals that were not previously associated with the disease and were new clusters of X-linked candidate gene. These structural modifications of the genome may have a role in phenotypic variation exerting their influence by modifying the 
expression of the genes varying in copy number or also of other genes mapping within or close to the rearranged region, affecting globally the transcriptome (Henrichsen et al. 2009). So far, the functional impact of most CNVs remains unknown; however, the collection of more a-CGH data from different cohorts may provide the basis for the identification of pathogenic CNVs and for the investigation on the contribution of individual genes to the genetic etiology of POF.

Moreover, epigenetics may help to elucidate genetic factors underlying common diseases, focusing not on DNA variations but on the regulation of gene expression by DNA methylation (Voorhuis et al. 2010). Epigenetic variations might indeed explain the quantitative nature of complex traits and the geneenvironment interaction in the onset of the disease in the perspective of further understanding the causes affecting the timing of premature menopause.

\section{Can genetic investigations in POI be useful for patients?}

On the basis of the references quoted in Table 1, the prevalence of known genetic alterations in POI patients can nowadays be estimated as ranging $20-25 \%$ of the cases originally classified as idiopathic. Therefore, the pathogenic mechanism still remains unknown in most cases. However, when a genetic alteration is found in a woman, it can be useful for family counseling because it can predict the female relatives that are at higher risk for POI and fertility loss in young age. The female carriers will thus be able to plan their conception before ovarian failure occurs. This possibility is becoming more and more important in this century as women tend to conceive more frequently in their thirties and forties, when the risk of POI in the general population is about $1-2 \%$. At present, a facility involved in the counseling of female infertility should consider screening women with idiopathic POI at least for the most prevalent genetic alterations, i.e. $\mathrm{X}$ chromosome abnormalities and FMR1 premutation (see Table 1). The finding of these abnormalities has obvious implications for family counseling beyond female fertility, including the risk of X-linked male mental retardation associated with FMR1 full mutation. More recent works may suggest the possibility of including the investigation of $B M P 15$ gene, and if the initial studies were confirmed FIGLA and NR5A 1 genes shall also be added to the study. The aim of several groups around the world, including ours, is to increase in the near future the sensitivity of genetic screening and possibly to develop a test for the prediction of menopausal age. This may indeed open the possibility of an efficient counseling service for female infertility and establish 'ad hoc' interventions for the prevention of the consequences of premature ovarian aging.

\section{Declaration of interest}

The authors declare that there is no conflict of interest that could be perceived as prejudicing the impartiality of this review.

\section{Funding}

The financial support from Telethon Foundation, Italy (grant no. GGP09126) and Istituto Auxologico Italiano, Italy (Ricerca Corrente Funds: 05C501) are gratefully acknowledged. RR is a fellow of Telethon Foundation, Italy.

\section{Acknowledgements}

We wish to thank the many clinicians referring their patients, as well as all the POF patients themselves who gave their informed consent for genetic studies. We also wish to acknowledge the continuous support of Paolo Beck-Peccoz (Milan, Italy), as well as the fruitful collaboration of Anna Marozzi and Daniela Toniolo (Milan, Italy).

\section{References}

Aboura A, Dupas C, Tachdjian G, Portnoï MF, Bourcigaux N, Dewailly D, Frydman R, Fauser B, Ronci-Chaix N, Donadille B et al. 2009 Array comparative genomic hybridization profiling analysis reveals deoxyribonucleic acid copy number variations associated with premature ovarian failure. Journal of Clinical Endocrinology and Metabolism 94 4540-4546. (doi:10.1210/jc.2009-0186)

Achermann JC, Ito M, Ito M, Hindmarsh PC \& Jameson JL 1999 A mutation in the gene encoding steroidogenic factor- 1 causes $\mathrm{XY}$ sex reversal and adrenal failure in humans. Nature Genetics $\mathbf{2 2}$ 125-126. (doi:10.1038/9629)

Aittomaki K, Lucerna JL, Pakarinen P, Sistonen P, Tapanainen JS, Gromoll J, Kaskikari R, Sankila EM, Lehvaslaiho H \& Engel AR 1995 Mutation in the follicle-stimulating hormone receptor gene causes hereditary hypergonadotropic ovarian failure. Cell 82 959-968. (doi:10.1016/0092-8674(95)90275-9)

Albright F, Burnett CH \& Smith CH 1942 Pseudohypoparathyroidism: an example of 'Sebright-Bantam syndrome'. Endocrinology 30 922-932.

Allen LA, Achermann JC, Pakarinen P, Kotlar TJ, Huhtaniemi IT, Jameson JL, Cheetham TD \& Ball SG 2003 A novel loss of function mutation in exon 10 of the FSH receptor gene causing hypergonadotrophic hypogonadism: clinical and molecular characteristics. Human Reproduction 18 251-256. (doi:10.1093/ humrep/deg046)

Allen EG, Sullivan AK, Marcus M, Small C, Dominguez C, Epstein MP, Charen K, He W, Taylor KC \& Sherman SL 2007 Examination of reproductive aging milestones among women who carry the FMR1 premutation. Human Reproduction 22 2142-2152. (doi:10.1093/ humrep/dem148)

Attisano L, Silvestri C, Izzi L \& Labbé E 2001 The transcriptional role of Smads and FAST (FoxH1) in TGF $\beta$ and activin signalling. Molecular and Cellular Endocrinology 180 3-11. (doi:10.1016/S03037207(01)00524-X)

Barlow C, Hirotsune S, Paylor R, Liyanage M, Eckhaus M, Collins F, Shiloh Y, Crawley JN, Ried T \& Tagle D 1996 Atm-deficient mice: a paradigm of ataxia telangiectasia. Cell 12 159-171. (doi:10.1016/ S0092-8674(00) 80086-0)

Bashamboo A \& McElreavey K 2010 NR5A1/SF-1 and development and function of the ovary. Annales d'Endocrinologie 71 177-182. (doi:10.1016/j.ando.2010.02.013) 
Beau I, Touraine P, Meduri G, Gougeon A, Desroches A, Matuchansky C, Milgrom E, Kuttenn F \& Misrahi M 1998 A novel phenotype related to partial loss of function mutations of the follicle stimulating hormone receptor. Journal of Clinical Investigation 102 1352-1359. (doi:10.1172/JCI3795)

Bennett CE, Conway GS, Macpherson JN, Jacobs PA \& Murray A 2010 Intermediate sized CGG repeats are not a common cause of idiopathic premature ovarian failure. Human Reproduction 25 1335-1338. (doi:10.1093/humrep/deq058)

Beysen D, Raes J, Leroy BP, Lucassen A, Yates JR, Clayton-Smith J, Ilyina H, Brooks SS, Christin-Maitre S, Fellous M et al. 2005 Deletions involving long-range conserved nongenic sequences upstream and downstream of FOXL2 as a novel disease-causing mechanism in blepharophimosis syndrome. American Journal of Human Genetics 77 205-218. (doi:10.1086/432083)

Beysen D, De Paepe A \& De Baere E 2009 Mutation update: FOXL2 mutations and genomic rearrangements in BPES. Human Mutation 30 158-169. (doi:10.1002/humu.20807)

Bharath R, Unnikrishnan AG, Thampy MV, Anilkumar A, Nisha B, Praveen VP, Nair V, Jayakumar RV \& Kumar H 2010 Turner syndrome and its variants. Indian Journal of Pediatrics 77 193-195. (doi:10.1007/s12098-009-0226-7)

Bione S, Sala C, Manzini C, Arrigo G, Zuffardi O, Banfi S, Borsani G, Jonveaux P, Philippe C, Zuccotti M et al. 1998 A human homologue of the Drosophila melanogaster diaphanous gene is disrupted in a patient with premature ovarian failure: evidence for conserved function in oogenesis and implications for human sterility. American Journal of Human Genetics 62 533-541. (doi:10.1086/301761)

Bione S, Rizzolio F, Sala C, Ricotti R, Goegan M, Manzini MC, Battaglia R, Marozzi A, Vegetti W, Dalprà R et al. 2004 Mutation analysis of two candidate genes for premature ovarian failure, DACH2 and POF1B. Human Reproduction 19 2759-2766. (doi:10.1093/humrep/deh502)

Bodega B, Porta C, Crosignani PG, Ginelli E \& Marozzi A 2004 Mutations in the coding region of the FOXL2 gene are not a major cause of idiopathic premature ovarian failure. Molecular Human Reproduction 10 555-557. (doi:10.1093/molehr/gah078)

Bodega B, Bione S, Dalprà L, Toniolo D, Ornaghi F, Vegetti W, Ginelli E \& Marozzi A 2006 Influence of intermediate and uninterrupted FMR1 CGG expansions in premature ovarian failure manifestation. Human Reproduction 21 952-957. (doi:10.1093/humrep/dei432)

Boder E 1975 Ataxia-telangiectasia: some historic, clinical and pathologic observations. Birth Defects Original Article Series 11 255-270.

Bodin L, Di Pasquale E, Fabre S, Bontoux M, Monget P, Persani L \& Mulsant P 2007 A novel mutation in the bone morphogenetic protein 15 gene causing defective protein secretion is associated with both increased ovulation rate and sterility in Lacaune sheep. Endocrinology 148 393-400. (doi:10.1210/en.2006-0764)

van Bokhoven H, Schwartz M, Andréasson S, van den Hurk JA, Bogerd L, Jay M, Rüther K, Jay B, Pawlowitzki IH, Sankila EM et al. 1994 Mutation spectrum in the CHM gene of Danish and Swedish choroideremia patients. Human Molecular Genetics 3 1047-1051. (doi:10.1093/hmg/3.7.1047)

Boltshauser E, Barth PG, Troost D, Martin E \& Stallmach T 2002 "Vanishing white matter" and ovarian dysgenesis in an infant with cerebro-oculo-facio-skeletal phenotype. Neuropediatrics 33 57-62. (doi:10.1055/s-2002-32363)

Bretherick KL, Fluker MR \& Robinson WP 2005 FMR1 repeat sizes in the gray zone and high end of the normal range are associated with premature ovarian failure. Human Genetics 117 376-382. (doi:10. 1007/s00439-005-1326-8)

Burton KA, Van Ee CC, Purcell K, Winship I \& Shelling AN 2000 Autosomal translocation associated with premature ovarian failure. Journal of Medical Genetics 37 e2. (doi:10.1136/jmg.37.5.e2)

Calderon FRO, Phansalkar AR, Crockett DK, Miller M \& Mao R 2007 Mutation database for the galactose-1-phosphate uridyltransferase (GALT) gene. Human Mutation 28 939-943. (doi:10.1002/humu. 20544)
Castrillon DH, Miao L, Kollipara R, Horner JW \& DePinho RA 2003 Suppression of ovarian follicle activation in mice by the transcription factor Foxo3a. Science 301 215-218. (doi:10.1126/science. 1086336)

Cervato S, Mariniello B, Lazzarotto F, Morlin L, Zanchetta R, Radetti G, De Luca F, Valenzise M, Giordano R, Rizzo D et al. 2009 Evaluation of the autoimmune regulator (AIRE) gene mutations in a cohort of Italian patients with autoimmune-polyendocrinopathy-candidiasisectodermal-dystrophy (APECED) and in their relatives. Clinical Endocrinology 70 421-428. (doi:10.1111/j.1365-2265.2008.03318.x)

Chand AL, Ponnampalam AP, Harris SE, Winship IM \& Shelling AN 2006 Mutational analysis of BMP15 and GDF9 as candidate genes for premature ovarian failure. Fertility and Sterility 86 1009-1012. (doi:10.1016/j.fertnstert.2006.02.107)

Chand AL, Ooi GT, Harrison CA, Shelling AN \& Robertson DM 2007 Functional analysis of the human inhibin alpha subunit variant A257T and its potential role in premature ovarian failure. Human Reproduction 22 3241-3248. (doi:10.1093/humrep/dem323)

Chand AL, Harrison CA \& Shelling AN 2010 Inhibin and premature ovarian failure. Human Reproduction Update 16 39-50. (doi:10.1093/ humupd/dmp031)

Chang H, Brown CW \& Matzuk MM 2002 Genetic analysis of the mammalian transforming growth factor-beta superfamily. Endocrine Reviews 23 787-823. (doi:10.1210/er.2002-0003)

Conway GS, Kaltsas G, Patel A, Davies MC \& Jacobs HS 1996 Characterization of idiopathic premature ovarian failure. Fertility and Sterility 65 337-341.

Cools M, Rooman RP, Wauters J, Jacqemyn Y \& Du Caju MV 2004 A nonmosaic 45,X karyotype in a mother with Turner's syndrome and in her daughter. Fertility and Sterility 82 923-925. (doi:10.1016/j. fertnstert.2004.02.129)

Corre T, Schuettler J, Bione S, Marozzi A, Persani L, Rossetti R, Torricelli F, Giotti I, Vogt P, Toniolo D et al. 2009 A large-scale association study to assess the impact of known variants of the human INHA gene on premature ovarian failure. Human Reproduction 24 2023-2028. (doi:10.1093/humrep/dep090)

Coulam CB, Adamson SC \& Annegers JF 1986 Incidence of premature ovarian failure. Obstetrics and Gynecology 67 604-606.

Cramer DW, Xu H \& Harlow BL 1995 Family history as a predictor of early menopause. Fertility and Sterility 64 740-745.

Crisponi L, Deiana M, Loi A, Chiappe F, Uda M, Amati P, Bisceglia L, Zelante L, Nagaraja R, Porcu S et al. 2001 The putative forkhead transcription factor FOXL2 is mutated in blepharophimosis/ ptosis/epicanthus inversus syndrome. Nature Genetics 27 159-166. (doi:10.1038/84781)

Davis GH 2004 Fecundity genes in sheep. Animal Reproduction Science 82-83 247-253. (doi:10.1016/j.anireprosci.2004.04.001)

Davis CJ, Davison RM, Payne NN, Rodeck CH \& Conway GS 2000 Female sex preponderance for idiopathic familial premature ovarian failure suggests an X chromosome defect: opinion. Human Reproduction 15 2418-2422. (doi:10.1093/humrep/15.11.2418)

De Baere E, Dixon MJ, Small KW, Jabs EW, Leroy BP, Devriendt K, Gillerot Y, Mortier G, Meire F, Van Maldergem L et al. 2001 Spectrum of FOXL2 gene mutations in blepharophimosis-ptosisepicanthus inversus (BPES) families demonstrates a genotypephenotype correlation. Human Molecular Genetics 10 1591-1600. (doi:10.1093/hmg/10.15.1591)

De Baere E, Lemercier B, Christin-Maitre S, Durval D, Messiaen L, Fellous M \& Veitia R 2002 FOXL2 mutation screening in a large panel of POF patients and XX males. Journal of Medical Genetics 39 e43. (doi:10.1136/jmg.39.8.e43)

De Baere E, Beysen D, Oley C, Lorenz B, Cocquet J, De Sutter P, Devriendt K, Dixon M, Fellous M, Fryns JP et al. 2003 FOXL2 and BPES: mutational hotspots, phenotypic variability, and revision of the genotype-phenotype correlation. American Journal of Human Genetics 72 478-487. (doi:10.1086/346118)

Demirhan O, Türkmen S, Schwabe GC, Soyupak S, Akgül E, Tastemir D, Karahan D, Mundlos S \& Lehmann K 2005 A homozygous 
BMPR1B mutation causes a new subtype of acromesomelic chondrodysplasia with genital anomalies. Journal of Medical Genetics 42 314-317. (doi:10.1136/jmg.2004.023564)

Di Pasquale E, Beck-Peccoz P \& Persani L 2004 Hypergonadotropic ovarian failure associated with an inherited mutation of human bone morphogenetic protein-15 (BMP15) gene. American Journal of Human Genetics 75 106-111. (doi:10.1086/422103)

Di Pasquale E, Rossetti R, Marozzi A, Bodega B, Borgato S, Cavallo L, Einaudi S, Radetti G, Russo G, Sacco M et al. 2006 Identification of new variants of human BMP15 gene in a large cohort of women with premature ovarian failure. Journal of Clinical Endocrinology and Metabolism 91 1976-1979. (doi:10.1210/jc.2005-2650)

Dixit H, Deendayal M \& Singh L 2004 Mutational analysis of the mature peptide region of inhibin genes in Indian women with ovarian failure. Human Reproduction 19 1760-1764. (doi:10.1093/ humrep/deh342)

Dixit H, Rao LK, Padmalatha V, Kanakavalli M, Deenadayal M, Gupta N, Chakravarty B \& Singh L 2005 Mutational screening of the coding region of growth differentiation factor 9 gene in Indian women with ovarian failure. Menopause 12 749-754. (doi:10.1097/01.gme.0000184424.96437.7a)

Dixit H, Rao LK, Padmalatha VV, Kanakavalli M, Deenadayal M, Gupta N, Chakrabarty B \& Singh L 2006 $a$ Missense mutations in the BMP15 gene are associated with ovarian failure. Human Genetics 119 408-415. (doi:10.1007/s00439-006-0150-0)

Dixit H, Rao KL, Padmalatha V, Kanakavalli M, Deenadayal M, Gupta N, Chakravarty BN \& Singh L 2006 $b$ Expansion of the germline analysis for the INHA gene in Indian women with ovarian failure. Human Reproduction 21 1643-1644. (doi:10.1093/humrep/del129)

Doherty E, Pakarinen P, Tiitinen A, Kiilavuori A, Huhtaniemi I, Forrest S \& Aittomaki K 2002 A novel mutation in the FSH receptor inhibiting signal transduction and causing primary ovarian failure. Journal of Clinical Endocrinology and Metabolism 87 1151-1155. (doi:10.1210/jc.87.3.1151)

Dong J, Albertini DF, Nishimori K, Kumar TR, Lu N \& Matzuk MM 1996 Growth differentiation factor-9 is required during early ovarian folliculogenesis. Nature 383 531-535. (doi:10.1038/ 383531a0)

Dube JL, Wang P, Elvin J, Lyons KM, Celeste AJ \& Matzuk MM 1998 The bone morphogenetic protein 15 gene is X-linked and expressed in oocytes. Molecular Endocrinology 12 1809-1817. (doi:10.1210/me.12.12.1809)

Elvin JA, Clark AT, Wang P, Wolfman NM \& Matzuk MM 1999 Paracrine actions of growth differentiation factor-9 in the mammalian ovary. Molecular Endocrinology 13 1035-1048. (doi:10.1210/me.13.6.1035)

Fabre S, Pierre A, Mulsant P, Bodin L, Di Pasquale E, Persani L, Monget P \& Monniaux D 2006 Regulation of ovulation rate in mammals: contribution of sheep genetic models. Reproductive Biology and Endocrinology 4 20. (doi:10.1186/1477-7827-4-20)

Falorni A, Laureti S, Candeloro P, Perrino S, Coronella C, Bizzarro A, Santeusanio F \& De Bellis A 2002 Steroid-cell autoantibodies are preferentially expressed in women with premature ovarian failure who have adrenal autoimmunity. Fertility and Sterility 78 270-279. (doi:10.1016/S0015-0282(02)03205-3)

Fechner PY, Davenport ML, Qualy RL, Ross JL, Gunther DF, Eugster EA, Huseman C, Zagar AJ, Quigley CA \& Toddler Turner Study Group 2006 Differences in follicle-stimulating hormone secretion between 45,X monosomy Turner syndrome and 45,X/46,XX mosaicism are evident at an early age. Journal of Clinical Endocrinology and Metabolism 91 4896-4902. (doi:10.1210/jc.2006-1157)

Finnish-German APECED Consortium 1997 An autoimmune disease, APECED, caused by mutations in a novel gene featuring two PHDtype zinc-finger domains. Nature Genetics 17 399-403. (doi:10.1038/ ng1297-399)

Fogli A, Rodriguez D, Eymard-Pierre E, Bouhour F, Labauge P, Meaney BF, Zeesman S, Kaneski CR, Schiffmann R \& Boespflug-Tanguy O
2003 Ovarian failure related to eukaryotic initiation factor 2B mutations. American Journal of Human Genetics 72 1544-1550. (doi:10.1086/375404)

Fogli A, Gauthier-Barichard F, Schiffmann R, Vanderhoof VH, Bakalov VK, Nelson LM \& Boespflug-Tanguy O 2004 Screening for known mutations in EIF2B genes in a large panel of patients with premature ovarian failure. BMC Women's Health 4 8. (doi:10.1186/ 1472-6874-4-8)

da Fonte Kohek MB, Batista MC, Russell AJ, Vass K, Giacaglia LR, Mendonca BB \& Latronico AC 1998 No evidence of the inactivating mutation (C566T) in the follicle-stimulating hormone receptor gene in Brazilian women with premature ovarian failure. Fertility and Sterility 70 565-567. (doi:10.1016/S0015-0282(98)00203-9)

Fraser IS, Russell P, Greco S \& Robertson DM 1986 Resistant ovary syndrome and premature ovarian failure in young women with galactosaemia. Clinical Reproduction and Fertility 4 133-138.

Galloway SM, McNatty KP, Cambridge LM, Laitinen MPE, Juengel JL, Jokiranta TS, McLaren RJ, Luiro K, Dodds KG, Montgomery GW et al. 2000 Mutations in an oocyte-derived growth factor gene (bmp15) cause increased ovulation rate and infertility in a dosagesensitive manner. Nature Genetics 25 279-283. (doi:10.1038/77033)

Gersak K, Harris SE, Smale WJ \& Shelling AN 2004 A novel 30 bp deletion in the FOXL2 gene in a phenotypically normal woman with primary amenorrhoea: case report. Human Reproduction 19 2767-2770. (doi:10.1093/humrep/deh496)

Ghadami M, Salama SA, Khatoon N, Chilvers R, Nagamani M, Chedrese PJ \& Al-Hendy A 2008 Toward gene therapy of primary ovarian failure: adenovirus expressing human FSH receptor corrects the Finnish C566T mutation. Molecular Human Reproduction 14 9-15. (doi:10.1093/molehr/gam077)

Ghadami M, El-Demerdash E, Salama SA, Binhazim AA, Archibong AE, Chen X, Ballard BR, Sairam MR \& Al-Hendy A 2010 Toward gene therapy of premature ovarian failure: intraovarian injection of adenovirus expressing human FSH receptor restores folliculogenesis in FSHR $(-/-)$ FORKO mice. Molecular Human Reproduction 16 241-250. (doi:10.1093/molehr/gaq003)

Goswami D \& Conway GS 2005 Premature ovarian failure. Human Reproduction Update 11 391-410. (doi:10.1093/humupd/dmi012)

Gubbels CS, Land JA \& Rubio-Gozalbo ME 2008 Fertility and impact of pregnancies on the mother and child in classic galactosemia. Obstetrical and Gynecological Survey 63 334-343. (doi:10.1097/OGX. 0b013e31816ff6c5)

Hanrahan JP, Gregan SM, Mulsant P, Mullen M, Davis GH, Powell R \& Galloway SM 2004 Mutations in the genes for oocyte-derived growth factors GDF9 and BMP15 are associated with both increased ovulation rate and sterility in Cambridge and Belclare sheep (Ovis aries). Biology of Reproduction 70 900-909. (doi:10.1095/biolreprod. 103.023093)

Harris SE, Chand AL, Winship IM, Gersak K, Aittomaki K \& Shelling AN 2002 Identification of novel mutations in FOXL2 associated with premature ovarian failure. Molecular Human Reproduction 8 729-733. (doi:10.1093/molehr/8.8.729)

Harris SE, Chand AL, Winship IM, Gersak K, Nishi Y, Yanase T, Nawata $\mathrm{H} \&$ Shelling AN 2005 INHA promoter polymorphisms are associated with premature ovarian failure. Molecular Human Reproduction 11 779-784. (doi:10.1093/molehr/gah219)

Hashimoto O, Moore RK \& Shimasaki S 2005 Posttranslational processing of mouse and human BMP-15: potential implication in the determination of ovulation quota. PNAS 102 5426-5431. (doi:10.1073/pnas.0409533102)

He C, Kraft P, Chen C, Buring JE, Paré G, Hankinson SE, Chanock SJ, Ridker PM, Hunter DJ \& Chasman DI 2009 Genome-wide association studies identify loci associated with age at menarche and age at natural menopause. Nature Genetics 41 724-728. (doi:10. 1038/ng.385)

Henrichsen CN, Chaignat E \& Reymond A 2009 Copy number variants, diseases and gene expression. Human Molecular Genetics 18 R1-R8. (doi:10.1093/hmg/ddp011) 
Hergersberg M, Matsuo K, Gassmann M, Schaffner W, Lüscher B, Rülicke T \& Aguzzi A 1995 Tissue-specific expression of a FMR1/beta-galactosidase fusion gene in transgenic mice. Human Molecular Genetics 4 359-366. (doi:10.1093/hmg/4.3.359)

Hussein TS, Froiland DA, Amato F, Thompson JG \& Gilchrist RB 2005 Oocytes prevent cumulus cell apoptosis by maintaining a morphogenic paracrine gradient of bone morphogenetic proteins. Journal of Cell Science 118 5257-5268. (doi:10.1242/jcs.02644)

Hussein TS, Thompson JG \& Gilchrist RB 2006 Oocyte-secreted factors enhance oocyte developmental competence. Developmental Biology 296 514-521. (doi:10.1016/j.ydbio.2006.06.026)

Jaeken J, Kint J \& Spaapen L 1992 Serum lysosomal enzyme abnormalities in galactosaemia. Lancet 340 1472-1473. (doi:10. 1016/0140-6736(92)92664-2)

Jeong HJ, Cho SW, Kim HA, Lee SH, Cho JH, Choi DH, Kwon H, Cha WT, Han JE \& Cha KY 2004 G769A variation of inhibin alpha-gene in Korean women with premature ovarian failure. Yonsei Medical Journal 45 479-482.

Jiang M, Aittomäki K, Nilsson C, Pakarinen P, Iitiä A, Torresani T, Simonsen H, Goh V, Pettersson K, de la Chapelle A et al. 1998 The frequency of an inactivating point mutation $(566 \mathrm{C} \rightarrow \mathrm{T})$ of the human follicle-stimulating hormone receptor gene in four populations using allele-specific hybridization and time-resolved fluorometry. Journal of Clinical Endocrinology and Metabolism 83 4338-4343. (doi:10.1210/jc.83.12.4338)

Jin P \& Warren ST 2000 Understanding the molecular basis of fragile X syndrome. Human Molecular Genetics 9 901-908. (doi:10.1093/hmg/ 9.6.901)

Kang H, Lee SK, Kim MH, Song J, Bae SJ, Kim NK, Lee SH \& Kwack K 2008 Parathyroid hormone-responsive B1 gene is associated with premature ovarian failure. Human Reproduction 23 1457-1465. (doi:10.1093/humrep/den086)

Kastan MB \& Bartek J 2004 Cell-cycle checkpoints and cancer. Nature 432 316-323. (doi:10.1038/nature03097)

van der Knaap MS, Pronk JC \& Scheper GC 2006 Vanihing white matter disease. Lancet Neurology 5 413-423. (doi:10.1016/S14744422(06) 70440-9)

Knauff EA, Franke L, van Es MA, van den Berg LH, van der Schouw YT, Laven JS, Lambalk CB, Hoek A, Goverde AJ, Christin-Maitre S et al. 2009 Genome-wide association study in premature ovarian failure patients suggests ADAMTS19 as a possible candidate gene. Human Reproduction 24 2372-2378. (doi:10.1093/humrep/dep197)

Kornak U \& Mundlos S 2003 Genetic disorders of the skeleton: a developmental approach. American Journal of Human Genetics 73 447-474. (doi:10.1086/377110)

Kovanci E, Rohozinski J, Simpson JL, Heard MJ, Bishop CE \& Carson SA 2007 Growth differentiating factor-9 mutations may be associated with premature ovarian failure. Fertility and Sterility $\mathbf{8 7}$ 143-146. (doi:10.1016/j.fertnstert.2006.05.079)

Kovanci E, Simpson JL, Amato P, Rohozinski J, Heard MJ, Bishop CE \& Carson SA 2008 Oocyte-specific G-protein-coupled receptor 3 (GPR3): no perturbations found in 82 women with premature ovarian failure (first report). Fertility and Sterility 90 1269-1271. (doi:10.1016/j.fertnstert.2007.07.1373)

Laissue P, Christin-Maitre S, Touraine P, Kuttenn F, Ritvos O, Aittomaki K, Bourcigaux N, Jacquesson L, Bouchard P, Frydman R et al. 2006 Mutations and sequence variants in GDF9 and BMP15 in patients with premature ovarian failure. European Journal of Endocrinology 154 739-744. (doi:10.1530/eje.1.02135)

Laissue P, Lakhal B, Benayoun BA, Dipietromaria A, Braham R, Elghezal H, Philibert P, Saâd A, Sultan C, Fellous M et al. 2009 Functional evidence implicating FOXL2 in non syndromic premature ovarian failure and in the regulation of the transcription factor OSR2. Journal of Medical Genetics 46 455-457. (doi:10.1136/ jmg.2008.065086)

Lakin ND, Weber P, Stankovic T, Rottinghaus ST, Taylor AM \& Jackson SP 1996 Analysis of the ATM protein in wild-type and ataxia telangiectasia cells. Oncogene 13 2707-2716.
Latronico AC, Anasti J, Arnhold IJ, Rapaport R, Mendonca BB, Bloise W, Castro M, Tsigos C \& Chrousos GP 1996 Brief report: testicular and ovarian resistance to luteinizing hormone caused by inactivating mutations of the luteinizing hormone-receptor gene. New England Journal of Medicine 334 507-512. (doi:10.1056/ NEJM199602223340805)

Latronico AC, Chai Y, Arnhold IJ, Liu X, Mendonca BB \& Segaloff DL 1998 A homozygous microdeletion in helix 7 of the luteinizing hormone receptor associated with familial testicular and ovarian resistance is due to both decreased cell surface expression and impaired effector activation by the cell surface receptor. Molecular Endocrinology 12 442-450. (doi:10.1210/me.12.3.442)

Layman LC 2006 Editorial: BMP15 - the first true ovarian determinant gene on the X-chromosome? Journal of Clinical Endocrinology and Metabolism 91 1673-1676. (doi:10.1210/jc.2006-0548)

Layman LC, Amde S, Cohen DP, Jin M \& Xie J 1998 The Finnish follicle-stimulating hormone receptor gene mutation is rare in North American women with 46,XX ovarian failure. Fertility and Sterility 69 300-302. (doi:10.1016/S0015-0282(97)00480-9)

Ledent C, Demeestere I, Blum D, Petermans J, Hämäläinen T, Smits G \& Vassart G 2005 Premature ovarian aging in mice deficient for Gpr3. PNAS 102 8922-8926. (doi:10.1073/pnas.0503840102)

Lehmann K, Seemann P, Stricker S, Sammar M, Meyer B, Süring K, Majewski F, Tinschert S, Grzeschik KH, Müller D et al. 2003 Mutations in bone morphogenetic protein receptor $1 \mathrm{~B}$ cause brachydactyly type A2. PNAS 100 12277-12282. (doi:10.1073/pnas. 2133476100)

Lin L, Philibert P, Ferraz-de-Souza B, Kelberman D, Homfray T, Albanese A, Molini V, Sebire NJ, Einaudi S, Conway GS et al. 2007 Heterozygous missense mutations in steroidogenic factor 1 (SF1/Ad4BP, NR5A1) are associated with 46,XY disorders of sex development with normal adrenal function. Journal of Clinical Endocrinology and Metabolism 92 991-999. (doi:10.1210/jc.2006-1672)

Liu G, Hale GE \& Hughes CL 2000 Galactose metabolism and ovarian toxicity. Reproductive Toxicology 14 377-384. (doi:10.1016/S08906238(00)00096-4)

Liu L, Rajareddy S, Reddy P, Du C, Jagarlamudi K, Shen Y, Gunnarsson D, Selstam G, Boman K \& Liu K 2007 Infertility caused by retardation of follicular development in mice with oocyte-specific expression of Foxo3a. Development 134 199-209. (doi:10.1242/dev.02667)

Livadas S, Xekouki P, Kafiri G, Voutetakis A, Maniati-Christidi M \& Dacou-Voutetakis C 2005 Spontaneous pregnancy and birth of a normal female from a woman with Turner syndrome and elevated gonadotropins. Fertility and Sterility 83 769-772. (doi:10.1016/j. fertnstert.2004.11.007)

Loesch DZ, Bui QM, Huggins RM, Mitchell RJ, Hagerman RJ \& Tassone F 2007 Transcript levels of the intermediate size or grey zone fragile $\mathrm{X}$ mental retardation 1 alleles are raised, and correlate with the number of CGG repeats. Journal of Medical Genetics $\mathbf{4 4}$ 200-204. (doi:10.1136/jmg.2006.043950)

Lourenço D, Brauner R, Lin L, De Perdigo A, Weryha G, Muresan M, Boudjenah R, Guerra-Junior G, Maciel-Guerra AT, Achermann JC et al. 2009 Mutations in NR5A1 associated with ovarian insufficiency. New England Journal of Medicine 360 1200-1210. (doi:10.1056/ NEJMoa0806228)

Loutradis D, Patsoula E, Stefanidis K, Drakakis P, Antonakis G, Bletsa R, Antsaklis A \& Michalas S 2006 Follicle-stimulating hormone receptor gene mutations are not evident in Greek women with premature ovarian failure and poor responders. Gynecologic and Obstetric Investigation 61 56-60. (doi:10.1159/000088658)

Luo X, Ikeda Y \& Parker KL 1994 A cell-specific nuclear receptor is essential for adrenal and gonadal development and sexual differentiation. Cell 77 481-490. (doi:10.1016/0092-8674(94)90211-9)

Luoma P, Melberg A, Rinne JO, Kaukonen JA, Nupponen NN, Chalmers RM, Oldfors A, Rautakorpi I, Peltonen L, Majamaa K et al. 2004 Parkinsonism, premature menopause, and mitochondrial DNA polymerase gamma mutations: clinical and molecular genetic study. Lancet 364 875-882. (doi:10.1016/S0140-6736(04) 16983-3) 
Mandon-Pépin B, Touraine P, Kuttenn F, Derbois C, Rouxel A, Matsuda F, Nicolas A, Cotinot C \& Fellous M 2008 Genetic investigation of four meiotic genes in women with premature ovarian failure. European Journal of Endocrinology 158 107-115. (doi:10.1530/EJE-07-0400)

Mansouri MR, Schuster J, Badhai J, Stattin EL, Lösel R, Wehling M, Carlsson B, Hovatta O, Karlström PO, Golovleva I et al. 2008 Alterations in the expression, structure and function of progesterone receptor membrane component-1 (PGRMC1) in premature ovarian failure. Human Molecular Genetics 17 3776-3783. (doi:10.1093/hmg/ddn274)

Mantovani G \& Spada A 2006 Mutations in the Gs alpha gene causing hormone resistance. Best Practice and Research. Clinical Endocrinology and Metabolism 20 501-513. (doi:10.1016/j.beem.2006.09.001)

Mantovani G, Ballare E, Giammona E, Beck-Peccoz P \& Spada A 2002 The gsalpha gene: predominant maternal origin of transcription in human thyroid gland and gonads. Journal of Clinical Endocrinology and Metabolism 87 4736-4740. (doi:10.1210/jc.2002-020183)

Marozzi A, Vegetti W, Manfredini E, Tibiletti MG, Testa G, Crosignani PG, Ginelli E, Meneveri R \& Dalprà L 2000 Association between idiopathic premature ovarian failure and fragile $\mathrm{X}$ premutation. Human Reproduction 15 197-202. (doi:10.1093/humrep/15.1.197)

Marozzi A, Porta C, Vegetti W, Crosignani PG, Tibiletti MG, Dalprà L \& Ginelli E 2002 Mutation analysis of the inhibin alpha gene in a cohort of Italian women affected by ovarian failure. Human Reproduction 17 1741-1745. (doi:10.1093/humrep/17.7.1741)

Mathis D \& Benoist C 2007 A decade of AIRE. Nature Reviews. Immunology 7 645-650. (doi:10.1038/nri2136)

Matzuk MM, Finegold MJ, Su JG, Hsueh AJ \& Bradley A 1992 Alphainhibin is a tumour-suppressor gene with gonadal specificity in mice. Nature 360 313-319. (doi:10.1038/360313a0)

Matzuk MM, Finegold MJ, Mather JP, Krummen L, Lu H \& Bradley A 1994 Development of cancer cachexia-like syndrome and adrenal tumors in inhibin-deficient mice. PNAS 91 8817-8821. (doi:10. 1073/pnas.91.19.8817)

McNatty KP, Moore LG, Hudson NL, Quirke LD, Lawrence SB, Reader K, Hanrahan JP, Smith P, Groome NP, Laitinen M et al. 2004 The oocyte and its role in regulating ovulation rate: a new paradigm in reproductive biology. Reproduction 128 379-386. (doi:10.1530/rep. 1.00280)

McNatty KP, Galloway SM, Wilson T, Smith P, Hudson NL, O'Connell A, Bibby AH, Heath DA, Davis GH, Hanrahan JP et al. 2005

Physiological effects of major genes affecting ovulation rate in sheep. Genetics, Selection, Evolution 37 (Suppl 1) S25-S38. (doi:10.1186/ 1297-9686-37-S1-S25)

Méduri G, Bachelot A, Duflos C, Bständig B, Poirot C, Genestie C, Veitia R, De Baere E \& Touraine P 2010 FOXL2 mutations lead to different ovarian phenotypes in BPES patients: case report. Human Reproduction 25 235-243. (doi:10.1093/humrep/dep355)

Mehlmann LM, Saeki Y, Tanaka S, Brennan TJ, Evsikov AV, Pendola FL, Knowles BB, Eppig JJ \& Jaffe LA 2004 The Gs-linked receptor GPR3 maintains meiotic arrest in mammalian oocytes. Science 306 19471950. (doi:10.1126/science.1103974)

Michels AW \& Gottlieb PA 2010 Autoimmune polyglandular syndromes. Nature Reviews. Endocrinology 6 270-277. (doi:10.1038/ nrendo.2010.40)

Miller ME \& Chatten J 1967 Ovarian changes in ataxia telangiectasia. Acta Paediatrica Scandinavica 56 559-561. (doi:10.1111/j.1651-2227. 1967.tb15424.x)

Montgomery GW, Zhao ZZ, Marsh AJ, Mayne R, Treloar SA, James M, Martin NG, Boomsma DI \& Duffy DL 2004 A deletion mutation in GDF9 in sisters with spontaneous DZ twins. Twin Research 7 548-555. (doi:10.1375/1369052042663823)

Morabia A, Costanza MC \& World Health Organization Collaborative Study of Neoplasia and Steroid Contraceptives 1998 International variability in ages at menarche, first livebirth, and menopause.

American Journal of Epidemiology 148 1195-1205.
Mumm S, Herrera L, Waeltz PW, Scardovi A, Nagaraja R, Esposito T, Schlessinger D, Rocchi M \& Forabosco A 2001 X/autosomal translocations in the $\mathrm{Xq}$ critical region associated with premature ovarian failure fall within and outside genes. Genomics 76 30-36. (doi:10.1006/geno.2001.6611)

Murabito JM, Yang Q, Fox C, Wilson PW \& Cupples LA 2005 Heritability of age at natural menopause in the Framingham Heart Study. Journal of Clinical Endocrinology and Metabolism 90 3427-3430. (doi:10.1210/jc.2005-0181)

Nagamine K, Peterson P, Scott HS, Kudoh J, Minoshima S, Heino M, Krohn KJE, Lalioti MD, Mullis PE, Antonarakis SE et al. 1997 Positional cloning of the APECED gene. Nature Genetics 17 393-398. (doi:10.1038/ng1297-393)

Nakamura Y, Maekawa R, Yamagata Y, Tamura I \& Sugino N 2008 A novel mutation in exon8 of the follicle-stimulating hormone receptor in a woman with primary amenorrhea. Gynecological Endocrinology 24 708-712. (doi:10.1080/09513590802454927)

Nallathambi J, Moumné L, De Baere E, Beysen D, Usha K, Sundaresan P \& Veitia R 2007 A novel polyalanine expansion in FOXL2: the first evidence for a recessive form of the blepharophimosis syndrome (BPES) associated with ovarian dysfunction. Human Genetics 121 107-112. (doi:10.1007/s00439-006-0276-0)

Nallathambi J, Laissue P, Batista F, Benayoun BA, Lesaffre C, Moumné L, Pandaranayaka PE, Usha K, Krishnaswamy S, Sundaresan P et al. 2008 Differential functional effects of novel mutations of the transcription factor FOXL2 in BPES patients. Human Mutation 29 E123-E131. (doi:10.1002/humu.20809)

Nelson LM 2009 Clinical practice. Primary ovarian insufficiency. New England Journal of Medicine 360 606-614. (doi:10.1056/ NEJMcp0808697)

Ogata T \& Matsuo N 1995 Turner syndrome and female sex chromosome aberrations: deduction of the principal factors involved in the development of clinical features. Human Genetics 95 607-629. (doi:10.1007/BF00209476)

Oldenburg RA, van Dooren MF, de Graaf B, Simons E, Govaerts L, Swagemakers S, Verkerk JM, Oostra BA \& Bertoli-Avella AM 2008 A genome-wide linkage scan in a Dutch family identifies a premature ovarian failure susceptibility locus. Human Reproduction $\mathbf{2 3}$ 2835-2841. (doi:10.1093/humrep/den278)

Oostra BA \& Willemsen R 2003 A fragile balance: FMR1 expression levels. Human Molecular Genetics 12 (Spec. No. 2) R249-R257. (doi:10.1093/hmg/ddg298)

Ornstein KS, McGuire EJ, Berry GT, Roth S \& Segal S 1992 Abnormal galactosylation of complex carbohydrates in cultured fibroblasts from patients with galactose-1-phosphate uridyltransferase deficiency. Pediatric Research 31 508-511. (doi:10.1203/00006450199205000-00020)

Pagnamenta AT, Taanman JW, Wilson CJ, Anderson NE, Marotta R, Duncan AJ, Bitner-Glindzicz M, Taylor RW, Laskowski A, Thorburn DR et al. 2006 Dominant inheritance of premature ovarian failure associated with mutant mitochondrial DNA polymerase gamma. Human Reproduction 21 2467-2473. (doi:10.1093/humrep/de1076)

Palmer JS, Zhao ZZ, Hoekstra C, Hayward NK, Webb PM, Whiteman DC, Martin NG, Boomsma DI, Duffy DL \& Montgomery GW 2006 Novel variants in growth differentiation factor 9 in mothers of dizygotic twins. Journal of Clinical Endocrinology and Metabolism 91 4713-4716. (doi:10.1210/jc.2006-0970)

Pasquino AM, Passeri F, Pucarelli I, Segni M \& Municchi G 1997 Spontaneous pubertal development in Turner's syndrome. Italian Study Group for Turner's syndrome. Journal of Clinical Endocrinology and Metabolism 82 1810-1813. (doi:10.1210/jc.82.6.1810)

Paterson P \& Peltonen L 2005 Autoimmune polyendocrinopathy syndrome type 1 (APS1) 963 and AIRE gene: new views on molecular basis of autoimmunity. Journal of Autoimmunity 25 49-55. (doi:10.1016/j.jaut.2005.09.022)

Patten JL \& Levine MA 1990 Immunochemical analysis of the alpha-subunit of the stimulatory G-protein of adenylyl cyclase in 
patients with Albright's hereditary osteodystrophy. Journal of Clinical Endocrinology and Metabolism 71 1208-1214. (doi:10.1210/ jcem-71-5-1208)

Perheentupa J 1996 Autoimmune polyendocrinopathy-candidiasisectodermal dystrophy (APECED). Hormone and Metabolic Research $\mathbf{2 8}$ 353-356. (doi:10.1055/s-2007-979814)

Perry JR, Stolk L, Franceschini N, Lunetta KL, Zhai G, McArdle PF, Smith AV, Aspelund T, Bandinelli S, Boerwinkle E et al. 2009 Meta-analysis of genome-wide association data identifies two loci influencing age at menarche. Nature Genetics 41 648-650. (doi:10. 1038/ng.386)

Persani L, Rossetti R, Cacciatore C \& Bonomi M 2009 Primary ovarian insufficiency: X chromosome defects and autoimmunity. Journal of Autoimmunity 33 35-41. (doi:10.1016/j.jaut.2009.03.004)

Pisarska MD, Bae J, Klein C \& Hsueh AJ 2004 Forkhead 12 is expressed in the ovary and represses the promoter activity of the steroidogenic acute regulatory gene. Endocrinology 145 3424-3433. (doi:10.1210/ en.2003-1141)

Prakash GJ, Kanth VV, Shelling AN, Rozati R \& Sujatha M 2009 Absence of 566C $>$ T mutation in exon 7 of the FSHR gene in Indian women with premature ovarian failure. International Journal of Gynecology and Obstetrics 105 265-266. (doi:10.1016/j.ijgo. 2009.01.023)

Prakash GJ, Ravi Kanth VV, Shelling AN, Rozati R \& Sujatha M 2010 Mutational analysis of inhibin alpha gene revealed three novel variations in Indian women with premature ovarian failure. Fertility and Sterility 94 90-98. (doi:10.1016/j.fertnstert.2009.02.014)

Prueitt RL \& Zinn AR 2001 A fork in the road to fertility. Nature Genetics 27 132-134. (doi:10.1038/84735)

Prueitt RL, Ross JL \& Zinn AR 2000 Physical mapping of nine Xq translocation breakpoints and identification of XPNPEP2 as a premature ovarian failure candidate gene. Cytogenetics and Cell Genetics 89 44-50. (doi:10.1159/000015560)

Prueitt RL, Chen H, Barnes RI \& Zinn AR 2002 Most X; autosome translocations associated with premature ovarian failure do not interrupt X-linked genes. Cytogenetic and Genome Research 97 32-38. (doi:10.1159/000064052)

Qin Y, Choi Y, Zhao H, Simpson JL, Chen ZJ \& Rajkovic A 2007 NOBOX homeobox mutation causes premature ovarian failure. American Journal of Human Genetics 81 576-581. (doi:10.1086/ 519496)

Qin Y, Shi Y, Zhao Y, Carson SA, Simpson JL \& Chen ZJ 2009 Mutation analysis of NOBOX homeodomain in Chinese women with premature ovarian failure. Fertility and Sterility 91 1507-1509. (doi:10.1016/j.fertnstert.2008.08.020)

Quilter CR, Karcanias AC, Bagga MR, Duncan S, Murray A, Conway GS, Sargent CA \& Affara NA 2010 Analysis of X chromosome genomic DNA sequence copy number variation associated with premature ovarian failure (POF). Human Reproduction 25 2139-2150. (doi:10.1093/humrep/deq158)

Raile K, Stobbe H, Tröbs RB, Kiess W \& Pfäffle R 2005 A new heterozygous mutation of the FOXL2 gene is associated with a large ovarian cyst and ovarian dysfunction in an adolescent girl with blepharophimosis/ptosis/epicanthus inversus syndrome. European Journal of Endocrinology 153 353-358. (doi:10.1530/eje.1. 01974)

Rajkovic A, Pangas SA, Ballow D, Suzumori N \& Matzuk MM 2004 NOBOX deficiency disrupts early folliculogenesis and oocyte-specific gene expression. Science 305 1157-1159. (doi:10. 1126/science.1099755)

Rannikko A, Pakarinen P, Manna PR, Beau I, Misrahi M, Aittomäki K \& Huhtaniemi I 2002 Functional characterization of the human FSH receptor with an inactivating Ala189Val mutation. Molecular Human Reproduction 8 311-317. (doi:10.1093/molehr/8.4.311)

Reynaud K, Cortvrindt R, Verlinde F, De Schepper J, Bourgain C \& Smitz J 2004 Number of ovarian follicles in human fetuses with the 45,X karyotype. Fertility and Sterility 81 1112-1119. (doi:10.1016/ j.fertnstert.2003.12.011)
Rifé M, Badenas C, Quintó L, Puigoriol E, Tazón B, RodriguezRevenga L, Jiménez L, Sánchez A \& Milà M 2004 Analysis of CGG variation through 642 meioses in fragile $\mathrm{X}$ families. Molecular Human Reproduction 10 773-776. (doi:10.1093/molehr/gah102)

Rizzolio F, Bione S, Sala C, Goegan M, Gentile M, Gregato G, Rossi E, Pramparo T, Zuffardi O \& Toniolo D 2006 Chromosomal rearrangements in $\mathrm{Xq}$ and premature ovarian failure: mapping of 25 new cases and review of the literature. Human Reproduction 21 1477-1483. (doi:10.1093/humrep/dei495)

Rizzolio F, Sala C, Alboresi S, Bione S, Gilli S, Goegan M, Pramparo T, Zuffardi O \& Toniolo D 2007 Epigenetic control of the critical region for premature ovarian failure on autosomal genes translocated to the X chromosome: a hypothesis. Human Genetics 121 441-450. (doi:10.1007/s00439-007-0329-z)

Rizzolio F, Pramparo T, Sala C, Zuffardi O, De Santis L, Rabellotti E, Calzi F, Fusi F, Bellazzi R \& Toniolo D 2009 Epigenetic analysis of the critical region I for premature ovarian failure: demonstration of a highly heterochromatic domain on the long arm of the mammalian X chromosome. Journal of Medical Genetics 46 585-592. (doi:10.1136/jmg.2007.056093)

Robinson ACR, Dockeray CJ, Cullen MJ \& Sweeney EC 1984 Hypergonadotrophic hypogonadism in classical galactosaemia: evidence for defective oogenesis: case report. British Journal of Obstetrics and Gynaecology 91 199-200.

Rossetti R, Di Pasquale E, Marozzi A, Bione S, Toniolo D, Grammatico P, Nelson LM, Beck-Peccoz P \& Persani L 2009 BMP15 mutations associated with primary ovarian insufficiency cause a defective production of bioactive protein. Human Mutation 30 804-810. (doi:10.1002/humu.20961)

Rubio-Gozalbo ME, Panis B, Zimmermann LJI, Spaapen LJ \& Menheere PPCA 2006 The endocrine system in treated patients with classical galactosemia. Molecular Genetics and Metabolism 89 316-322. (doi:10.1016/j.ymgme.2006.07.005)

Rubio-Gozalbo ME, Gubbels CS, Bakker JA, Menheere PP, Wodzig WK \& Land JA 2010 Gonadal function in male and female patients with classic galactosemia. Human Reproduction Update 16 177-188. (doi:10.1093/humupd/dmp038)

Sauer MV, Kaufman FR, Paulson RJ \& Lobo RA 1991 Pregnancy after oocyte donation to a woman with ovarian failure and classical galactosemia. Fertility and Sterility 55 1197-1199.

Savitsky K, Bar-Shira A, Gilad S, Rotman G, Ziv Y, Vanagaite L, Tagle DA, Smith S, Uziel T, Sfez S et al. 1995 A single ataxia telangiectasia gene with a product similar to PI-3 kinase. Science 268 1749-1753. (doi:10.1126/science.7792600)

Schiffmann R, Tedeschi G, Kinkel RP, Trapp BD, Frank JA, Kaneski CR, Brady RO, Barton NW, Nelson L \& Yanovski JA 1997 Leukodystrophy in patients with ovarian dysgenesis. Annals of Neurology 41 654-661. (doi:10.1002/ana.410410515)

Schlessinger D, Herrera L, Crisponi L, Mumm S, Percesepe A, Pellegrini M, Pilia G \& Forabosco A 2002 Genes and translocations involved in POF. American Journal of Medical Genetics 111 328-333. (doi:10.1002/ajmg.10565)

Schmidt D, Ovitt CE, Anlag K, Fehsenfeld S, Gredsted L, Treier AC \& Treier M 2004 The murine winged-helix transcription factor Foxl2 is required for granulosa cell differentiation and ovary maintenance. Development 131 933-942. (doi:10.1242/dev.00969)

Schwarz HP, Moser H, Schild J \& Zuppinger K 1984 Hypergonadotropic hypogonadism in two sisters with galactosaemia. Archives of Disease in Childhood 59 781-783. (doi:10.1136/adc.59.8.781)

Sedgwick RP \& Boder E 1991 Ataxia-telangiectasia. In Handook of Clinical Neurology, pp 347-423. Eds P Vinken, G Bruyn \& H Klawans. New York: Elsevier

Shelling AN, Burton KA, Chand AL, van Ee CC, France JT, Farquhar CM, Milsom SR, Love DR, Gersak K, Aittomäki K et al. 2000 Inhibin: a candidate gene for premature ovarian failure. Human Reproduction 15 2644-2649. (doi:10.1093/humrep/15.12.2644)

Shiloh Y 2003 ATM and related protein kinases: safeguarding genome integrity. Nature Reviews. Cancer 3 155-168. (doi:10.1038/nrc1011) 
Shimasaki S, Moore RK, Otsuka F \& Erickson GF 2004 The bone morphogenetic protein system in mammalian reproduction. Endocrine Reviews 25 72-101. (doi:10.1210/er.2003-0007)

Simpson JL 2008 Genetic and phenotypic heterogeneity in ovarian failure: overview of selected candidate genes. Annals of the New York Academy of Sciences 1135 146-154. (doi:10.1196/annals. 1429.019)

Sparks SE \& Krasnewich DM 2009 Congenital disorders of glycosylation overview. In Gene Reviews. Eds RA Pagon, TC Bird, CR Dolan \& K Stephens. Seattle: University of Washington.

Steinmann B, Gitzelmann R \& Zachmann M 1981 Hypogonadism and galactosemia. New England Journal of Medicine 305 464-465. (doi:10.1056/NEJM198111193052127)

Sundblad V, Chiauzzi VA, Andreone L, Campo S, Charreau EH \& Dain L 2006 Controversial role of inhibin alpha-subunit gene in the aetiology of premature ovarian failure. Human Reproduction 21 1154-1160. (doi:10.1093/humrep/dei452)

Sybert VP \& McCauley E 2004 Turner's syndrome. New England Journal of Medicine 351 1227-1238. (doi:10.1056/NEJMra030360)

Takebayashi K, Takakura K, Wang H, Kimura F, Kasahara K \& Noda Y 2000 Mutation analysis of the growth differentiation factor-9 and $9 \mathrm{~B}$ genes in patients with premature ovarian failure and polycystic ovary syndrome. Fertility and Sterility 74 976-979. (doi:10.1016/ S0015-0282(00) 01539-9)

Tassone F, Hagerman RJ, Taylor AK, Gane LW, Godfrey TE \& Hagerman PJ 2000 Elevated levels of FMR1 mRNA in carrier males: a new mechanism of involvement in the fragile-X syndrome. American Journal of Human Genetics 66 6-15. (doi:10.1086/302720)

Tavtigian SV, Oefner PJ, Babikyan D, Hartmann A, Healey S, Le CalvezKelm F, Lesueur F, Byrnes GB, Chuang SC, Forey N et al. 2009 Rare, evolutionarily unlikely missense substitutions in ATM confer increased risk of breast cancer. American Journal of Human Genetics 85 427-446. (doi:10.1016/j.ajhg.2009.08.018)

Tedesco TA \& Miller KL 1979 Galactosemia: alterations in sulfate metabolism secondary to galactose-1-phosphate uridyltransferase deficiency. Science 205 1395-1397. (doi:10.1126/science.472754)

Themmen APN \& Huhtaniemi IT 2000 Mutations of gonadotropins and gonadotropin receptors: elucidating the physiology and pathophysiology of pituitary-gonadal function. Endocrine Reviews 21 551-583. (doi:10.1210/er.21.5.551)

Therman E, Laxova R \& Susman B 1990 The critical region on the human Xq. Human Genetics 85 455-461. (doi:10.1007/BF00194216)

Tibiletti MG, Testa G, Vegetti W, Alagna F, Taborelli M, Dalprà L, Bolis PF \& Crosignani PG 1999 The idiopathic forms of premature menopause and early menopause show the same genetic pattern. Human Reproduction 14 2731-2734. (doi:10.1093/humrep/14.11.2731)

Timmreck LS \& Reindollar RH 2003 Contemporary issues in primary amenorrhea. Obstetrics and Gynecology Clinics of North America 30 287-302. (doi:10.1016/S0889-8545(03)00027-5)

Tiotiu D, Mercadal BA, Imbert R, Verbist J, Demeestere I, De Leener A, Englert Y, Vassart G, Costagliola S \& Delbaere A 2010 Variants of the BMP15 gene in a cohort of patients with premature ovarian failure. Human Reproduction 25 1581-1587. (doi:10.1093/humrep/deq073)

Toniolo D 2006 X-linked premature ovarian failure: a complex disease. Current Opinion in Genetics E Development 16 293-300. (doi:10.1016/ j.gde.2006.04.005)

Torgerson DJ, Thomas RE \& Reid DM 1997 Mothers and daughters menopausal ages: is there a link? European Journal of Obstetrics, Gynecology, and Reproductive Biology 74 63-66. (doi:10.1016/S03012115(97)00085-7)

Touraine P, Beau I, Gougeon A, Meduri G, Desroches A, Pichard C, Detoeuf M, Paniel B, Prieur M, Zorn JR et al. 1999 New natural inactivating mutations of the follicle-stimulating hormone receptor: correlations between receptor function and phenotype. Molecular Endocrinology 13 1844-1854. (doi:10.1210/me.13.11.1844)

Tyfield L, Reichardt J, Fridovich-Keil J, Croke DT, Elsas LJ, Strobl W, Kozak L, Coskun T, Novelli G \& Okano Y 1999 Classical galactosemia and mutations at the galactose-1-phosphate uridyl transferase (GALT) gene. Human Mutation 13 417-430. (doi:10.1002/ (SICI) 1098-1004(1999) 13:6 < 417::AID-HUMU1 > 3.0.CO;2-0)

Uda M, Ottolenghi C, Crisponi L, Garcia JE, Deiana M, Kimber W, Forabosco A, Cao A, Schlessinger D \& Pilia G 2004 Foxl2 disruption causes mouse ovarian failure by pervasive blockage of follicle development. Human Molecular Genetics 13 1171-1181. (doi:10.1093/hmg/ddh124)

Vegetti W, Grazia Tibiletti M, Testa G, de Lauretis Yankowski, Alagna F, Castoldi E, Taborelli M, Motta T, Bolis PF, Dalprá L et al. 1998 Inheritance in idiopathic premature ovarian failure: analysis of 71 cases. Human Reproduction 13 1796-1800. (doi:10.1093/humrep/ 13.7.1796)

Vinci G, Christin-Maitre S, Pasquier M, Bouchard P, Fellous M \& Veitia RA 2008 FOXO3a variants in patients with premature ovarian failure. Clinical Endocrinology 68 495-497. (doi:10.1111/j. 1365-2265.2007.03052.x)

Voorhuis M, Onland-Moret NC, van der Schouw YT, Fauser BC \& Broekmans FJ 2010 Human studies on genetics of the age at natural menopause: a systematic review. Human Reproduction Update 16 364-377. (doi:10.1093/humupd/dmp055)

Waggoner DD, Buist NR \& Donnell GN 1990 Long-term prognosis in galactosaemia: results of a survey of 350 cases. Journal of Inherited Metabolic Disease 13 802-818. (doi:10.1007/ BF01800204)

Wang B, Wen Q, Ni F, Zhou S, Wang J, Cao Y \& Ma X 2010 Analyses of growth differentiation factor 9 (GDF9) and bone morphogenetic protein 15 (BMP15) mutation in Chinese women with premature ovarian failure. Clinical Endocrinology 72 135-136. (doi:10.1111/j. 1365-2265.2009.03613.x)

Watkins WJ, Umbers AJ, Woad KJ, Harris SE, Winship IM, Gersak K \& Shelling AN 2006 Mutational screening of FOXO3A and FOXO1A in women with premature ovarian failure. Fertility and Sterility $\mathbf{8 6}$ 1518-1521. (doi:10.1016/j.fertnstert.2006.03.054)

Weinstein LS, Liu J, Sakamoto A, Xie T \& Chen M 2004 Minireview: GNAS: normal and abnormal functions. Endocrinology 1455459 5464. (doi:10.1210/en.2004-0865)

Welt CK 2008 Primary ovarian insufficiency: a more accurate term for premature ovarian failure. Clinical Endocrinology 68 499-509. (doi:10.1111/j.1365-2265.2007.03073.x)

Wilson T, Wu XY, Juengel JL, Ross IK, Lumsden JM, Lord EA, Dodds KG, Walling GA, McEwan JC, O'Connell AR et al. 2001 Highly prolific Booroola sheep have a mutation in the intracellular kinase domain of bone morphogenetic protein IB receptor (ALK-6) that is expressed in both oocytes and granulosa cells. Biology of Reproduction 64 1225-1235. (doi:10.1095/biolreprod64.4.1225)

Wittenberger MD, Hagerman RJ, Sherman SL, McConkie-Rosell A, Welt CK, Rebar RW, Corrigan EC, Simpson JL \& Nelson LM 2007 The FMR1 premutation and reproduction. Fertility and Sterility 87 456-465. (doi:10.1016/j.fertnstert.2006.09.004)

Woad KJ, Pearson SM, Harris SE, Gersak K \& Shelling AN 2009 Investigating the association between inhibin alpha gene promoter polymorphisms and premature ovarian failure. Fertility and Sterility 91 62-66. (doi:10.1016/j.fertnstert.2007.11.012)

Yan C, Wang P, DeMayo J, DeMayo FJ, Elvin JA, Carino C, Prasad SV, Skinner SS, Dunbar BS, Dube JL et al. 2001 Synergistic roles of bone morphogenetic protein 15 and growth differentiation factor 9 in ovarian function. Molecular Endocrinology 15 854-866. (doi:10.1210/ me.15.6.854)

Yi SE, LaPolt PS, Yoon BS, Chen JY-C, Lu JKH \& Lyons KM 2001 The type I BMP receptor BmprIB is essential for female reproductive function. PNAS 98 7994-7999. (doi:10.1073/pnas.141002798)

Zhao XX, Suzumori N, Yamaguchi M \& Suzumori K 2005 Mutational analysis of the homeobox region of the human NOBOX gene in Japanese women who exhibit premature ovarian failure. Fertility and Sterility 83 1843-1844. (doi:10.1016/ j.fertnstert.2004.12.031) 
Zhao H, Qin Y, Kovanci E, Simpson JL, Chen ZJ \& Rajkovic A 2007 Analyses of GDF9 mutation in 100 Chinese women with premature ovarian failure. Fertility and Sterility 88 1474-1476. (doi:10.1016/ j.fertnstert.2007.01.021)

Zhao H, Chen ZJ, Qin Y, Shi Y, Wang S, Choi Y, Simpson JL \& Rajkovic A 2008a Transcription factor FIGLA is mutated in patients with premature ovarian failure. American Journal of Human Genetics $\mathbf{8 2}$ 1342-1348. (doi:10.1016/j.ajhg.2008.04.018)

Zhao ZZ, Painter JN, Palmer JS, Webb PM, Hayward NK, Whiteman DC, Boomsma DI, Martin NG, Duffy DL \& Montgomery GW $2008 b$ Variation in bone morphogenetic protein 15 is not associated with spontaneous human dizygotic twinning. Human Reproduction 23 2372-2379. (doi:10.1093/humrep/den268)

Zhou S, Wang B, Ni F, Wang J, Cao Y \& Ma X 2010 GPR3 may not be a potential candidate gene for premature ovarian failure. Reproductive Biomedicine Online 20 53-55. (doi:10.1016/j.rbmo.2009.10.013)
Zinn AR 2001 The X chromosome and the ovary. Journal of the Society for Gynecologic Investigation 8 S34-S36. (doi:10.1016/S10715576(00)00104-0)

Zinn AR \& Ross JL 1998 Turner syndrome and haploinsufficiency. Current Opinion in Genetics and Development 8 322-327. (doi:10.1016/ S0959-437X(98) 80089-0)

Zinn AR, Tonk VS, Chen Z, Flejter WL, Gardner HA, Guerra R, Kushner H, Schwartz S, Sybert VP, Van Dyke DL et al. 1998 Evidence for a Turner syndrome locus or loci at Xp11.2-p22.1. American Journal of Human Genetics 63 1757-1766. (doi:10.1086/302152)

Received in final form 2 July 2010

Accepted 28 July 2010

Made available online as an Accepted Preprint 28 July 2010 